\title{
22. DISSECTING AN ACTIVE HYDROTHERMAL DEPOSIT: THE STRONTIUM AND OXYGEN ISOTOPIC ANATOMY OF THE TAG HYDROTHERMAL MOUND-WHOLE ROCK AND SILICATE MINERALS ${ }^{1}$
}

\author{
Damon A.H. Teagle, ${ }^{2}$ Jeffrey C. Alt, ${ }^{2}$ Susan E. Humphris, ${ }^{3}$ and Alex N. Halliday ${ }^{2}$
}

\begin{abstract}
Recent drilling during Leg 158 of the Ocean Drilling Program penetrated the Trans-Atlantic Geotraverse (TAG) Hydrothermal Mound and recovered a unique suite of samples that allow the description of the subsurface anatomy of an active hydrothermal deposit. Strontium- and oxygen-isotopic compositions of whole-rock samples and quartz separates, combined with petrographic observations, provide important constraints on the physical and chemical nature of fluid-rock interactions, and the compositions of fluids, during alteration of basalt and sulfide mineralization in the active TAG hydrothermal deposit.

Fresh mid-ocean ridge basalt (MORB), with a ${ }^{87} \mathrm{Sr} /{ }^{86} \mathrm{Sr}$ of 0.7026 , from the basement beneath of the TAG mound was altered at both low and high temperatures by seawater and altered at high temperature by near end-member hydrothermal fluids. Pillow breccias occurring beneath the margins of the hydrothermal mound are completely recrystallized to chlorite by interaction with large volumes of conductively heated seawater $\left(>200^{\circ} \mathrm{C}\right)$.

The development of a silicified, sulfide-mineralized stockwork within the basaltic basement follows a simple paragenetic sequence of initial chloritization by hot, Mg-bearing hydrothermal fluids, followed by mineralization by Mg-depleted black smoker-type fluids and the development of the paragonite + quartz + pyrite stockwork cut by quartz-pyrite veins.

The initial high-temperature interaction and alteration in the TAG basement involved the development of chloritic alteration halos around the rims of basaltic clasts. The fluid responsible for this interaction was $\mathrm{Mg}$-bearing and most probably a mixture of upwelling, high-temperature $\left(>300^{\circ} \mathrm{C}\right)$, black smoker-type fluid with a minor $(« 10 \%)$ proportion of seawater. Continued high-temperature $\left(>300^{\circ} \mathrm{C}\right)$ interaction between the wallrock and initially $\mathrm{Mg}$-bearing hydrothermal fluids results in the complete recrystallization of the wallrock to chlorite + quartz + pyrite.

The hydrothermal assemblage of paragonite + quartz + pyrite overprints the chloritized basalts. This assemblage developed because of reaction at high temperatures $\left(250^{\circ}-360^{\circ} \mathrm{C}\right)$ with magnesium-depleted, hydrothermal fluids. End-member hydrothermal fluids had ${ }^{87} \mathrm{Sr} /{ }^{86} \mathrm{Sr} \approx 0.7038$, similar to present-day vent fluids. The uniformity of the ${ }^{87} \mathrm{Sr} /{ }^{86} \mathrm{Sr}$ ratios of hydrothermal assemblages throughout the mound and stockwork requires that the ${ }^{87} \mathrm{Sr} /{ }^{86} \mathrm{Sr}$ ratio of end-member hydrothermal fluids has remained relatively constant for a time period longer than that required to change the interior thermal structure and plumbing network of the mound and underlying stockwork.

The precipitation of anhydrite in breccias and as late-stage veins throughout most of the mound and stockwork, down to at least $125 \mathrm{mbsf}$, records extensive entrainment of seawater and mixing with hydrothermal fluids. In contrast, the silicification and sulfide mineralization that dominate the stockwork and interior of the mound occurred by interaction of end-member black smoker fluids with basalt and early hydrothermally altered rocks, with limited conductive cooling. The dilution of hydrothermal fluids by mixing with seawater played only a minor role in the development of the main quartz + paragonite + pyrite stockwork.
\end{abstract}

\section{INTRODUCTION}

The interaction between seawater and newly formed crust at midocean ridge spreading margins has profound consequences for the thermal structure of the ocean crust (Lister, 1972; Stein and Stein, 1994) and acts as an important source or sink of many elements into the oceans (e.g., Palmer and Edmond, 1989). To date, most studies of hydrothermal vents have involved sampling fluid chemistries (e.g., Von Damm et al., 1985; Campbell et al., 1988; James et al., 1995), or the collection of sulfide chimneys and other rock types from the surface of hydrothermal deposits by dredging or submersible (Haymon and Kastner, 1981; Rona et al., 1993; Hannington et al., 1995; Tivey et al., 1995). These studies have provided detailed descriptions of the chimney structures that provide conduits for hydrothermal fluids and of the sulfide and metallogenic sediments (German et al., 1993; Mills et al., 1993; Masuda et al., 1995) that form a carapace to some larger

${ }^{1}$ Herzig, P.M., Humphris, S.E., Miller, D.J., and Zierenberg, R.A. (Eds.), 1998. Proc. ODP, Sci. Results, 158: College Station, TX (Ocean Drilling Program).

${ }^{2}$ Department of Geological Sciences, 2534 C.C. Little Building, The University of Michigan, Ann Arbor, MI 48109-1063, U.S.A. Teagle: teagle@ umich.edu

${ }^{3}$ Department of Geology and Geophysics, Woods Hole Oceanographic Institution, Woods Hole, MA 02543, U.S.A. sulfide deposits; but to date, there is that little direct evidence as to the subsurface nature of black smoker systems. Thermodynamic modeling of fluid compositions (Janecky and Seyfried, 1984; Bowers et al., 1988) and geochemical investigations of hydrothermal precipitates (Tivey et al., 1995; Mills and Elderfield, 1995) provide some indications as to the reactions that must be occurring within hydrothermal mounds. In particular, recent studies have highlighted the important role that seawater entrainment, conductive heating or cooling, fluid mixing, mineral precipitation and dissolution, and reprecipitation processes have on the chemistry of hydrothermal effluents (e.g., Tivey et al., 1995; Mills and Elderfield, 1995; James and Elderfield, 1996).

Other investigations (e.g., Constantinou and Govett, 1973; Zierenberg et al., 1988) have described massive sulfide deposits preserved in ophiolites, which are thought to be ancient analogs of the active mid-ocean ridge systems. Although the ophiolites commonly provide excellent three-dimensional exposures of massive sulfide deposits and their underlying stockwork mineralization, these descriptions are commonly complicated by metamorphism, low-temperature seafloor weathering, and post-depositional tectonic activity. In particular, because of its retrograde solubility, anhydrite is absent from ancient massive sulfide deposits, with any that was once present having dissolved during cooling after the termination of active mineral-

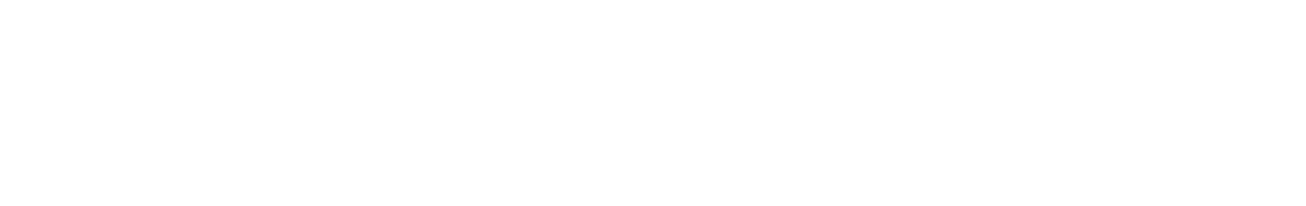


ization. Recent studies have suggested that anhydrite reprecipitation plays an important role in the evolution of hydrothermal effluent chemistry (Mills and Elderfield, 1995; James and Elderfield, 1996).

Recent drilling during Leg 158 of the Ocean Drilling Program penetrated the Trans-Atlantic Geotraverse (TAG) Hydrothermal Mound and recovered unique samples that allow the description of the subsurface anatomy of an active hydrothermal deposit and provide important constraints on fluid interactions and mineralization processes (Humphris et al., 1995; Humphris, Herzig, Miller, et al., 1996). In this paper we present and interpret new strontium- and oxygen-isotope analyses of whole-rock samples and mineral separates recovered from the TAG mound during drilling operations at Site 957. Descriptions of the mineralogy and petrology of samples (Honnorez et al., Chap. 18, this volume), whole-rock major- and trace-element chemistry (Humphris et al., Chap. 19, this volume), detailed oxygen-isotopic analyses (Alt and Teagle, Chap. 21, this volume) and of the geochemistry of anhydrite (Chiba et al., Chap. 6; Mills et al., Chap. 10; Teagle et al., Chap. 11; all in this volume) can be found in companion papers to this manuscript.

\section{Geological Setting of the TAG Hydrothermal Mound, Mid-Atlantic Ridge}

Since the discovery of chemical anomalies in the seawater column, thought to result from hydrothermal venting along the MidAtlantic Ridge (Rona et al., 1975), the TAG hydrothermal field has been the principal locus of hydrothermal investigations in the Atlantic Ocean (Edmond et al., 1979; Campbell et al., 1988; Rona et al., 1986; Thompson et al., 1988, Elderfield et al., 1993; Tivey, 1995; Tivey et al., 1995). The geological setting of the TAG hydrothermal field has been recently reviewed in detail by Rona et al. (1993) and Humphris, Herzig, Miller, et al. (1996) and will be briefly summarized.

Low- and high-temperature hydrothermal activity and extinct relict sulfide deposits occupy a $5 \mathrm{~km} \times 5 \mathrm{~km}$ area on the eastern floor and rift valley of the Mid-Atlantic Ridge. The field is located at approximately $26^{\circ} 08^{\prime} \mathrm{N}$ at the middle of a $40-\mathrm{km}$-long, north-northeasttrending segment of ridge, one of 15 segments bounded by nontransform offsets between the Atlantis $\left(30^{\circ} \mathrm{N}\right)$ and the Kane $\left(24^{\circ} \mathrm{N}\right)$ Fracture Zones (Fig. 1). All hydrothermal activity discovered to date has been located to the east of the neovolcanic zone that defines the ridge axis. Low-temperature activity occurs at mid-depth (2300-3100 m) on the east wall of the rift valley with the patchy distribution of warm springs $\left(<20^{\circ} \mathrm{C}\right)$ and ferromanganiferous crusts (Thompson et al., 1985). Inactive sulfide deposits, highly weathered and dissected by faulting and mass wasting, are present on the lower slopes of the east median valley wall at the Mir and Alvin hydrothermal zones (Fig. 1). These sites comprise discontinuous exposures of sulfide debris, relict inactive hydrothermal chimneys interspersed with red metalliferous sediments, and carbonate ooze.

The present site of active hydrothermal venting was discovered in 1985 (Rona et al., 1986) 1.5-2 km east of the ridge axis in water depths of 3630-3670 m. Here, a large sulfide mound, approximately $200 \mathrm{~m}$ in diameter and up to $50 \mathrm{~m}$ high, is the site of a variety of styles of focused high-temperature $\left(>350^{\circ} \mathrm{C}\right)$ hydrothermal fluid vents and lower temperature diffuse flow. Assuming a linear spreading rate (1.3 $\mathrm{cm} / \mathrm{yr}$; McGregor et al., 1977), the TAG hydrothermal mound is situated on crust at least $100 \mathrm{k} . y$. old. The deposit itself partially overlaps the northwest margin of a dome of fractured pillow lavas with variable cover of pelagic sediment $(\approx 1 \mathrm{~m}$ thick; Rona et al., 1986; Zonenshain et al., 1989). Karson and Rona (1990) have suggested that the mound's location marks the intersection between axis-parallel normal faults and the westward projection of an axis-transverse transfer fault mapped on a reentrant of the eastern wall of the median valley. Recent detailed surveys of the TAG mound utilizing high-res- olution sidescan sonar imagery and near-bottom photography (Kleinrock et al., 1996) found no clear evidence for young volcanic structures in the vicinity of the TAG mound. Their survey suggests that the mound is located in a region of closely spaced, rift-parallel (northnortheast) fissures at the intersection of this zone with a series of preexisting obliquely oriented (east-northeast) faults, though these features do not appear to link to structures on the eastern median valley wall, as has been suggested by Karson and Rona (1990).

The apparent longevity of hydrothermal venting at this site is evidenced by the size of the deposit, which requires an enduring interplay between volcanic and tectonic processes that have developed a basement permeability structure able to focus upwelling fluids at this site for a considerable time period. Radiometric dating of hydrothermal precipitates from the TAG mound suggest that hydrothermal activity has occurred at this site episodically for over 40-50 k.y. (Lalou et al., 1993; 1995; Chap. 9, this volume).

The active TAG mound is a steep-sided structure approximately $200 \mathrm{~m}$ in diameter with up to $50 \mathrm{~m}$ relief. The mound is distinctly subcircular in plan view and surrounded by an apron, up to $100 \mathrm{~m}$ wide, of carbonate and metalliferous sediments (Fig. 2). Distinct platforms, at $3650 \mathrm{~m}$ and $3644 \mathrm{~m}$, suggest at least two phases of mound growth. The present location of concentrated high-temperature fluid venting is atop a conical structure, $10-15 \mathrm{~m}$ high and $20-30 \mathrm{~m}$ in diameter at the base, northwest of the center of the mound (Fig. 2). This Black Smoker Complex comprises a cluster of chimneys (up to $15 \mathrm{~m}$ high) that vent fluids up to $363^{\circ} \pm 3^{\circ} \mathrm{C}$ (Edmond et al., 1995). The lower platform is approximately $100 \mathrm{~m}$ wide, with an irregular surface comprising sulfide debris, talus, standing and toppled chimneys, and iron oxide crusts. Low-temperature diffuse flow (up to $50^{\circ} \mathrm{C}$ ) occurs across the mound, though it is most concentrated near the central black smoker edifice. In the southeast quadrant of the mound, a community of more that 10 , squat, bulbous chimneys (the "Kremlin" area; Thompson et al., 1988) issue $260^{\circ}$ to $300^{\circ} \mathrm{C}$ white smoker fluids.

Near-bottom geophysical surveys conducted from submersibles provide some constraints on the subsurface structure of the TAG deposit. A magnetization low located directly beneath the mound with a possible southward plunge has been interpreted as the alteration pipe of the upflow zone beneath the deposit (Tivey et al., 1993). Onbottom gravity measurements conducted and modeled by Evans (1996), however, show no evidence of a dense sulfide root extending deep into the basement beneath the mound.

Conductive heat flow across the mound and its surroundings (Becker and Von Herzen, 1996) is generally high, though measurements are commonly complicated by the upward passage of diffuse hydrothermal fluids through the sediment cover, and are biased by measuring heat flow only where "sediment ponds" are developed. Elevated heat flow clearly indicates that mound-related thermal effects and fluid-flow processes extend in the subsurface beyond the extent of the mound. However, a swath of very low heat flow $\left(<20 \mathrm{~mW} / \mathrm{m}^{2}\right)$ on the western section of the main platform of the TAG mound, within 20 to $50 \mathrm{~m}$ of the Black Smoker Complex, indicates the local recharge of ocean bottom water into the mound (Fig. 2; Becker and Von Herzen, 1996).

\section{Rock Types and Stratigraphy of the TAG Mound and Underlying Stockwork from Leg 158 Results}

Seventeen holes were drilled at five different locations (TAG 15; see Figs. 2, 3) on the TAG mound to define the subsurface nature and lateral heterogeneity of the active mound and its underlying zone of stockwork alteration and mineralization. Shipboard scientists classified 20 different rock types in the TAG drill core (Humphris, Herzig, Miller, et al., 1996). As each piece of core, typically only a few centimeters long, was classified individually, the stratigraphy is 


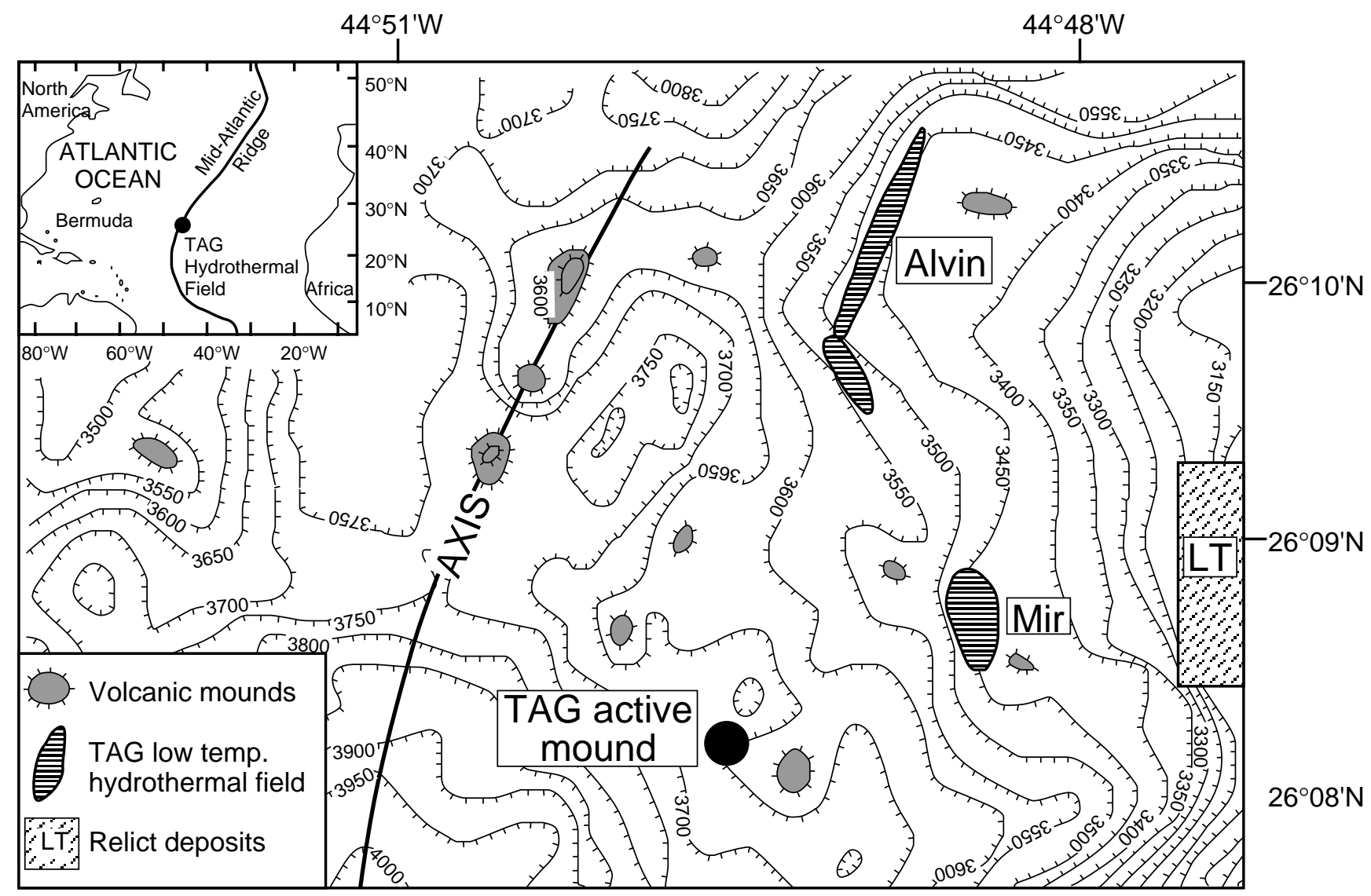

Figure 1. Location map of the TAG hydrothermal field on the Mid-Atlantic Ridge (inset). Bathymetry and hydrothermal features of the TAG hydrothermal field (after Rona et al., 1993). The TAG active mound is positioned on 100-k.y.-old crust to the east of the axis of spreading. Relict sulfide deposits (Alvin and Mir) and low-temperature hydrothermal fields are located to the north and east of the active mound.

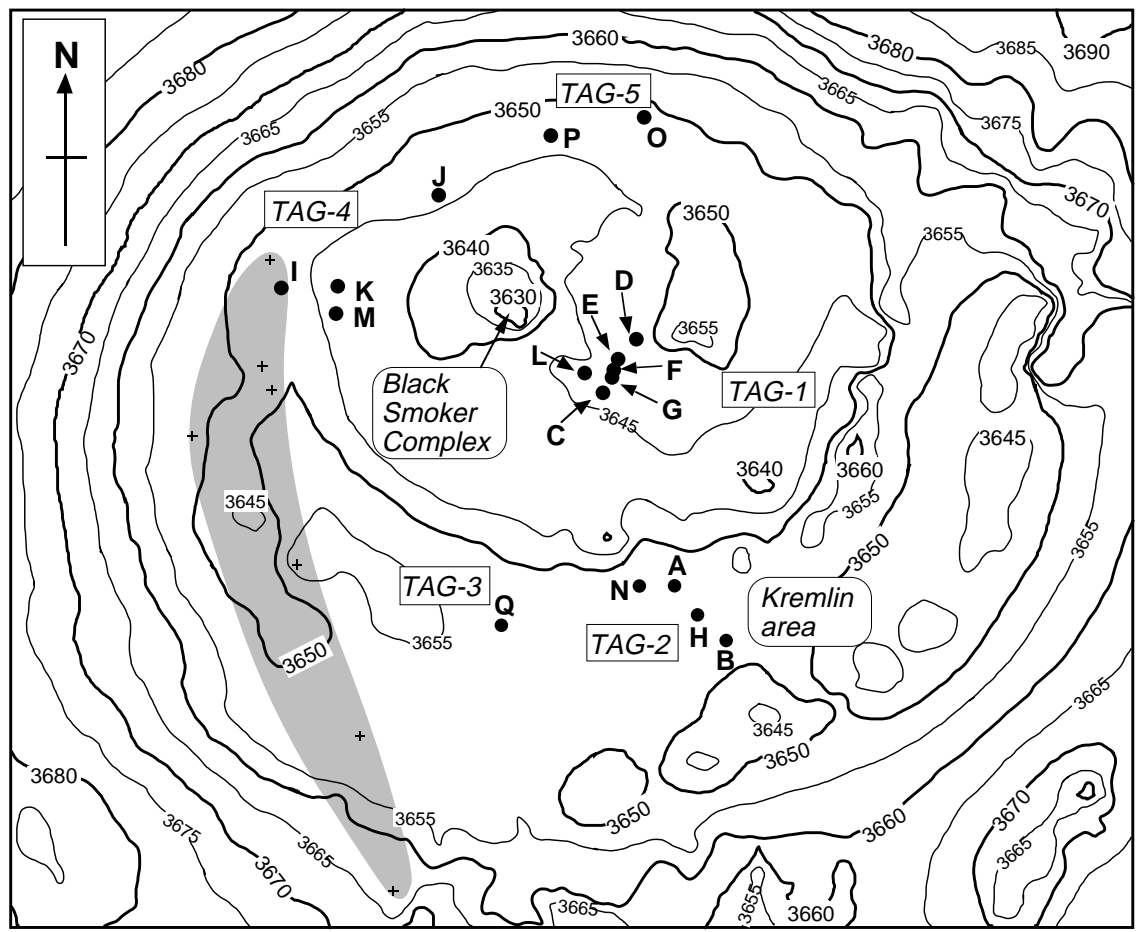

$\begin{array}{lllll}10 & 20 & 30 & 40 & 50 \mathrm{~m}\end{array}$
Figure 2. Detailed bathymetry of the TAG mound and locations of Leg 158 drill holes at Site 957 (solid circles). Drill holes are grouped into five areas (TAG-1 through TAG-5). See text for detailed descriptions. Bathymetric contour interval is $5 \mathrm{~m}$ (after Humphris, Herzig, Miller, et al., 1996). Shaded region to the west of the main Black Smoker Complex indicates the north-south-trending zone of anomalously low conductive heat flow $(<20 \mathrm{~mW} /$ $\mathrm{m}^{2}$ ), potentially an area of local recharge of ocean bottom water into the mound (Becker and Von Herzen, 1996). 


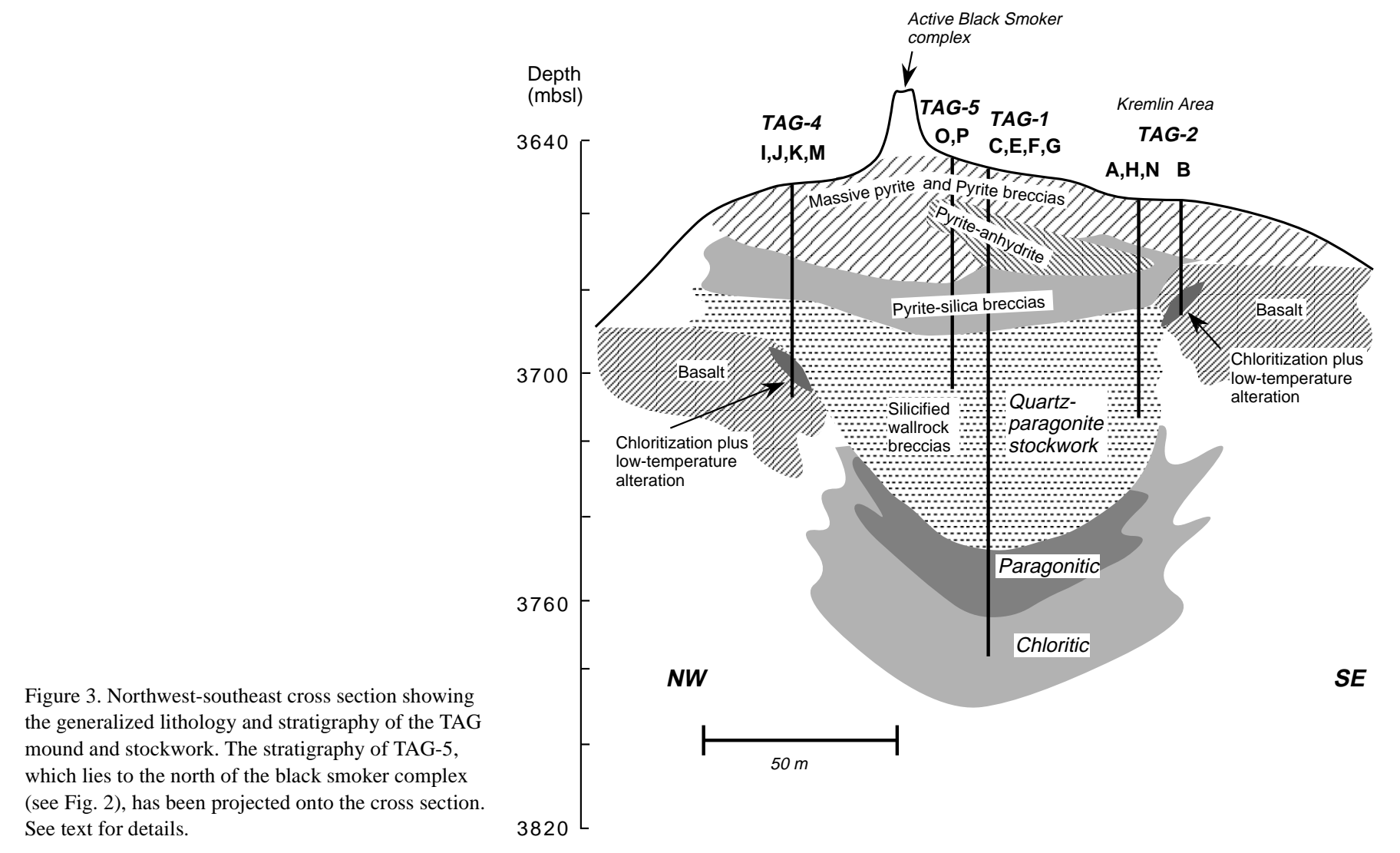

complicated at a fine scale. At a larger scale however, the mound can be divided into relatively few lithologic zones, and a simplified stratigraphy for the hydrothermal deposits is summarized in Figure 3.

The uppermost 5-20 m of the mound consists mainly of pyrite breccias that contain clasts of pyrite or massive pyrite in a pyrite matrix. These breccias also contain local concentrations of chalcopyrite and sphalerite, plus common minor quartz and/or anhydrite in the matrix. Near the Black Smoker Complex in the central and northern parts of the mound (TAG-1 and TAG- 5 areas), the pyrite breccias are underlain by a 10 - to $15-\mathrm{m}$-thick anhydrite-rich zone. This zone consists of mainly pyrite-anhydrite breccias that contain clasts of pyrite \pm siliceous material (quartz + pyrite, silicified basalt fragments, clasts of other quartz-rich breccias) in a matrix containing greater than $10 \%$ anhydrite. Anhydrite veins are common locally in these rocks. The massive pyrite breccias and anhydrite-rich rocks are in turn underlain by pyrite-silica breccias, which consist of clasts of pyrite, quartz + pyrite, and/or siliceous material, in a quartz-rich $(>10 \%)$ matrix. Anhydrite veins, up to $45 \mathrm{~cm}$ wide and exhibiting multiple stages of precipitation and dissolution, are common in the pyrite-silica breccias at TAG-1, and smaller (millimeter- to centimeter-sized) anhydrite veins are common in the pyrite-silica breccias at TAG-2 and TAG-5.

Variable proportions of silicified wallrock breccias occur with pyrite-silica breccias below 25-35 meters below seafloor (mbsf) at TAG-1, TAG-4, and TAG-5. Altered and silicified basalt clasts become much more abundant in the pyrite-silica breccias below this depth, which marks the top of the stockwork zone. The silicified wallrock breccias consist of pale gray to buff fragments of silicified basalt that are veined and cemented by quartz and pyrite. Basalt clasts are totally replaced by quartz, paragonite, pyrite, a microcrystalline Ti-bearing phase, and traces of chlorite (Honnorez et al., Chap. 18, this volume). The clasts are veined and cemented by $0.01-$ to $2-\mathrm{mm}$ veins of quartz \pm pyrite, which in some cases form vein-nets, and many of the quartz veins, at least in part, replacing basalt. Some silic- ified basalt clasts are cemented by gray, fine-grained, pyrite-bearing quartz veins, which are up to several centimeters wide and contain small fragments of silicified basaltic material. Veins of massive pyrite \pm chalcopyrite \pm quartz are present locally, particularly at TAG4 and TAG-5. Late anhydrite veins are common throughout, except at TAG-4, where anhydrite is notably absent.

At TAG-1, paragonitized basalt breccias occur below $101 \mathrm{mbsf}$ (Fig. 3). These are essentially identical to the silicified wallrock breccias, but are softer and appear less intensely silicified in hand specimen. Chloritized basalt breccias are present below $111 \mathrm{mbsf}$ at TAG1. These rocks are altered to chlorite, quartz, and pyrite, and are green in hand specimen. Along abundant quartz + pyrite veins, the green chloritized rocks are replaced first by gray paragonitized material in centimeter-sized alteration halos, and then are more silicified toward the vein or breccia matrix.

The stockwork feeder zone at TAG is zoned vertically and exhibits lateral variations. The siliceous stockwork begins at about 25-35 mbsf in the pyrite-silica breccias and continues downward in the silicified wallrock breccias, which contain the quartz + paragonite + pyrite assemblage (Fig. 3). Below $101 \mathrm{mbsf}$ the rocks of the sericitic or paragonitic stockwork are less silicified and contain the assemblage paragonite + quartz + pyrite. At $111 \mathrm{mbsf}$, the chloritic stockwork begins, with chlorite + quartz + pyrite and paragonite + quartz + pyrite assemblages.

Silicified wallrock breccias of the stockwork at TAG-1 and TAG2 are siliceous, whereas those at TAG- 4 and TAG-5, although they contain the same phases, are more pyritic. Massive pyrite is common, cementing and partly replacing altered basalt clasts at both sites, and at TAG-4 the clasts are noticeably less silicified. TAG-5 thus may be a pyritic variation of the siliceous stockwork, but TAG-4 probably represents a talus pile. The altered basalt clasts at TAG- 4 are smaller and more rounded than at TAG-1, and the silicified wallrock breccias at TAG-4 are clast supported and lack the pervasive quartz veining 
observed elsewhere. Anhydrite is absent at TAG-4. There is an abrupt transition downward from silicified breccias to partly altered basalt, suggesting that the silicified wallrock breccias at TAG-4 are not part of the stockwork but rather represent a talus pile cemented by pyrite \pm quartz.

Basaltic basement penetrated at TAG-4 and in Hole 957B at TAG-2 constrains the width of the TAG stockwork near the surface to about $90 \mathrm{~m}$ (Fig. 3). At TAG-4, the basement consists of dark gray basalt with centimeter-sized green chloritized halos. Small amounts of chloritized glass and massive hydrothermal quartz probably represent interpillow material. The dark gray basalt is $5 \%-15 \%$ altered, with olivine, vesicles, and interstitial areas partly to totally altered or filled with smectite (saponite) and talc. The chloritic alteration halos are zoned and about $1 \mathrm{~cm}$ wide. The outer zones are about $80 \%$ altered with plagioclase, olivine, pyroxene, and interstitial areas replaced and vesicles filled by chlorite and mixed-layer chlorite-smectite. The inner zones, closer to the gray altered basalt cores, are less altered $(\approx 30 \%)$ and igneous plagioclase is preserved (Honnorez et al., Chap. 18, this volume).

At TAG-2, basement consists of a 30-cm section of hydrothermally altered pillow breccia overlying slightly altered basalt. The breccia consists of millimeter- to centimeter-sized fragments of basalt and glass replaced by chlorite, cemented by chlorite and quartz, and with many clasts stained red by hematite. A single centimeter-sized fragment of hydrothermal quartz cementing chloritized glass shards is also present. Pieces of basalt are dark gray and slightly altered, with smectite replacing olivine and filling pores. Rimming some fragments are red alteration halos, $1-5 \mathrm{~mm}$ wide, where the rock is totally recrystallized to chlorite and stained red by hematite.

Samples recovered from the TAG mound can be broadly classified into (1) altered basalts that retain some relict igneous phases, and (2) hydrothermal assemblages in which the primary minerals have been completely replaced by or recrystallized to hydrothermal minerals, and the original texture has either been obliterated or preserved as pseudomorphic shadow. Mineral and textural characteristic of the seven alteration subclassifications used in this paper are summarized in Table 1.

\section{SAMPLING AND METHODS}

The samples studied are representative of the various types of material recovered from the TAG mound during Leg 158, and include least altered rocks as well as more intensely altered basalts and breccias. Secondary minerals were studied in transmitted and reflected light, and identifications were aided by electron microprobe analysis.
Detailed petrographic information and mineral compositions of the samples analyzed in this paper are reported by Honnorez et al. (Chap. 18 , this volume). Oxygen- and strontium-isotopic compositions of anhydrite liberated from breccias and veins that cut across these and other samples are presented in Teagle et al. (Chap. 11, this volume).

Whole-rock samples, representative of the different mineralization and alteration styles present at Site 957, were selected for geochemical analysis after petrographic characterization. Zones of differing alteration were separated by sawing, where possible. Whole-rock samples were ground in chrome steel at Woods Hole Oceanographic Institution, and splits of these powders were distributed for chemical analysis (major and trace elements; see Humphris et al., Chap. 19, this volume) and strontium- and oxygen-isotopic composition determinations (see also Alt and Teagle, Chap. 21, this volume).

Strontium-isotopic compositions were determined by thermal ionization mass spectrometry in the Radiogenic Isotope Geochemistry Laboratory at the University of Michigan. Approximately 10 to 30 mg of powdered whole-rock sample underwent a standard $\mathrm{HF}-\mathrm{HNO}_{3}$ dissolution. Aqua regia was applied to samples rich in sulfides to assist dissolution. Samples were evaporated to incipient dryness then taken up in $0.2 \mathrm{~mL}$ of $3 \mathrm{M} \mathrm{HNO}_{3}$ before loading on fresh, cleaned $\mathrm{Sr}$ Spec columns with a resin bed volume of $\approx 0.07 \mathrm{~mL}$. Major elements were eluted with $1 \mathrm{~mL}$ of $3 \mathrm{M} \mathrm{HNO}_{3}$ before collecting $\mathrm{Sr}$ in $1 \mathrm{~mL}$ of $\mathrm{H}_{2} \mathrm{O}$.

Strontium-isotopic compositions $\left({ }^{87} \mathrm{Sr} /{ }^{86} \mathrm{Sr}\right)$ were determined by loading on single Re filaments with a $\mathrm{TaCl}_{5}$ solution and $5 \%$ phosphoric acid. Samples were analyzed on a V.G. Sector-II multiple collector mass spectrometer ("Damian"), using a $2.0 \pm 0.2 \times 10^{-11} \mathrm{~A}$ ion beam with at least 200 ratios collected in a multidynamic mode and normalized to ${ }^{86} \mathrm{Sr} /{ }^{88} \mathrm{Sr}=0.1194$. Samples were analyzed for ${ }^{87} \mathrm{Sr} /{ }^{86} \mathrm{Sr}$ at two separate intervals. For samples analyzed in 1995, the National Institution of Science and Technology $\mathrm{Sr}$ isotopic standard, NIST SRM 987, gave ${ }^{87} \mathrm{Sr} /{ }^{86} \mathrm{Sr}=0.710237 \pm 0.000013(2 \sigma, n=61)$. However, for analyses conducted in 1996, NIST SRM 987 gave ${ }^{87} \mathrm{Sr} /{ }^{86} \mathrm{Sr}$ $=0.710214 \pm 0.000018(2 \sigma, n=20)$, because of subtle changes in machine operating parameters. Samples analyzed in 1996 have been normalized to a standard value for NIST SRM 987 of ${ }^{87} \mathrm{Sr} /{ }^{86} \mathrm{Sr}=$ 0.710237 for consistency in the data reported in Table 2 . Full analytical procedural blanks were $<50 \mathrm{pg}$ for $\mathrm{Sr}$.

Strontium and zirconium concentrations of whole-rock powders reported in Table 2, were determined by inductively coupled plasmamass spectrometry (ICP-MS) using methods described by Humphris et al. (Chap. 19, this volume). Oxygen-isotopic ratios were measured on quartz separates and on bulk-rock powders following procedures

Table 1. Summary of the mineral and textural characteristics used to classify altered basalts and hydrothermal assemblages from the TAG hydrothermal mound and stockwork.

Classification

(Abbreviation)

Altered basalts

Gray basalts $(\mathrm{G})$

Chloritic alteration halos $(\mathrm{C})$

Hydrothermal assemblages Altered pillow breccia $(\mathrm{P})$ Chloritized basalt breccia (Cbx) Paragonitized basalt breccia $(\mathrm{Pbx})$ Silicified wallrock breccia (Wbx)

Silicified basaltic clasts (SC)
Mineral and textural descriptions

\footnotetext{
$5 \%$ to $15 \%$ altered with olivine, vesicles, and interstitial areas partly to totally altered to smectite (saponite), and talc. Fresh olivine is present in some samples.

$60 \%$ to $80 \%$ altered with olivine, pyroxene, vesicles, and interstitial areas replaced/filled by chlorite and/or mixed layer chlorite/smectite.

Fragments of glass and basalt ( $\mathrm{mm}$ - to $\mathrm{cm}$-sized) replaced by chlorite in a matrix of chlorite, \pm quartz \pm hematite. Green rocks comprising chlorite, quartz, and pyrite

Gray rocks comprising paragonite, quartz, and pyrite. Replaces chloritized basalt along margins of quartz + pyrite veins.

Pale gray to buff basalts and breccia, replaced by quartz, paragonite, and pyrite, and minor phases (chlorite, Ti-phase) and strongly veined and cemented by quartz and pyrite.

Clasts of altered basalt similar to silicified wallrock breccia: totally replaced by quartz, paragonite, pyrite, and minor phases (chlorite, Tiphase).
}

Note: For rock classification symbols, see Figure 4 
Table 2. Strontium- and oxygen-isotopic compositions of whole-rock samples and quartz separates from the TAG hydrothermal mound.

\begin{tabular}{|c|c|c|c|c|c|c|c|c|c|}
\hline Core, section, interval $(\mathrm{cm})$ & $\begin{array}{l}\text { Depth } \\
\text { (mbsf) }\end{array}$ & Description & Classification & ${ }^{87} \mathrm{Sr} /{ }^{86} \mathrm{Sr} \pm 2 \sigma$ & $\begin{array}{c}\mathrm{Zr} \\
(\mathrm{ppm})\end{array}$ & $\begin{array}{c}\mathrm{Sr} \\
(\mathrm{ppm})\end{array}$ & $\begin{array}{c}\mathrm{Sr}^{*} \\
(\mathrm{ppm})\end{array}$ & $\begin{array}{c}\delta^{18} \mathrm{O}, \% o \\
\text { (WR) }\end{array}$ & $\begin{array}{l}\delta^{18} \mathrm{O}, \% o \\
\text { (quartz) }\end{array}$ \\
\hline \multicolumn{10}{|l|}{ TAG-1 Central } \\
\hline \multicolumn{10}{|l|}{$158-957 \mathrm{C}-$} \\
\hline $7 \mathrm{~N}-3,47-49$ (Piece $4 \mathrm{~A})$ & 22.82 & $\begin{array}{l}\text { Silicified basalt clast, } 5 \% \text { anhydrite veins } \\
\text { (illififien }\end{array}$ & $\underset{\mathrm{SC}}{\mathrm{SC}}$ & $0.707057 \pm 0.000010$ & 18 & 187 & 1022 & & \\
\hline $11 \mathrm{~N}-3,109-111$ (Piece 10A) & 34.70 & $\begin{array}{l}\text { Silicified (+pyrite) clast, } 10 \% \text { pyrite }+ \text { silicified matrix material } \\
\text { Sijlicified }\end{array}$ & SC & & 24 & 73 & 299 & & \\
\hline $14 \mathrm{~N}-2,22-27$ (Piece 1C) & 41.17 & & Wbx & $0.705676 \pm 0.000010$ & 14 & 19 & 133 & & 8.5 \\
\hline 16N-2, 69-73 (Piece 7B) & 48.30 & Silicified basalt, no visible veins & $\mathrm{SC}$ & $0.704058 \pm 0.000011$ & 15 & 17 & 111 & & \\
\hline \multicolumn{10}{|l|}{$158-957 \mathrm{E}-$} \\
\hline 6R-1, 11-13 (Piece 3) & 63.4 & Silicified wallrock breccia, intensely silicified & Wbx & $0.704043 \pm 0.000010$ & 20 & 36 & 177 & & 9.8 \\
\hline $8 \mathrm{R}-1,15-20$ (Piece 3) & 72.95 & Silicified basalt, no visible veins & $\mathrm{SC}$ & $0.703863 \pm 0.000011$ & 21 & 18 & 84 & & 11.4 \\
\hline 14R-1, 41-44 (Piece 10) & 101.90 & Paragonitized basalt breccia (intensely silicified) & $\mathrm{Pbx}$ & $0.703816 \pm 0.000010$ & 24 & 34 & 139 & & $10.0,8.3$ \\
\hline $16 \mathrm{R}-1,14-16$ (Piece 3) & 111.29 & Green chloritized basalt breccia, intensely silicified, quartz vein net & $\mathrm{Cbx}$ & $0.703856 \pm 0.000011 \dagger$ & 85 & 22 & 25 & 7.1 & \\
\hline 18R-1, 4-7 (Piece 1) & 120.00 & Green chloritized basalt breccia, $1 \%$ pyrite veins & $\mathrm{Cbx}$ & $0.704181 \pm 0.000020$ & 66 & 3 & 4 & 2.1 & \\
\hline 18R-1, 20-24 (Piece 4, gray) & 120.90 & Gray paragonitized basalt breccia, intensely silicified, quartz vein net & $\mathrm{Pbx}$ & $0.704223 \pm 0.000008 \dagger$ & 30 & 47 & 154 & 10.1 & \\
\hline 18R-1, 45-47 (Piece 9) & 121.40 & Green chloritized basalt breccia, $20 \%$ pyrite + quartz veins & $\mathrm{Cbx}$ & $0.703979 \pm 0.000008$ & 34 & 6 & 17 & 5.7 & \\
\hline \multicolumn{10}{|l|}{ TAG-2 Kremlin } \\
\hline \multirow{2}{*}{\multicolumn{10}{|c|}{ 158-957B- }} \\
\hline 4R-1, 17-24 (Piece 2) & 20.07 & & $\mathrm{P}$ & $0.708225 \pm 0.000010 \dagger$ & 123 & 13 & 10 & 2.6 & \\
\hline 4R-1, 39-41 (Piece 4) & 20.29 & & $\mathrm{P}$ & $0.708464 \pm 0.000010$ & 119 & 9 & 7 & 2.9 & \\
\hline 4R-1, 55-62 (Piece 8) & 20.45 & Dark gray basalt, shipboard X-ray fluorescence (XRF) powder & G & $0.702615 \pm 0.000010$ & 96 & 116 & 119 & 5.9 & \\
\hline \multicolumn{10}{|l|}{$158-957 \mathrm{H}-$} \\
\hline $5 \mathrm{~N}-1,44-47$ (Piece 5B) & 27.14 & Intensely silicified basalt clast, quartz + pyrite vein net & $\mathrm{SC}$ & $0.706067 \pm 0.000010 \dagger$ & 15 & 31 & 203 & & \\
\hline 9X-1, 1-3 (Piece 1) & 45.00 & Silicified wallrock breccia, intensely silicified, quartz + pyrite vein net & Wbx & $0.704610 \pm 0.000011$ & 9 & 6 & 66 & & 8.3 \\
\hline \multicolumn{10}{|l|}{ TAG-4 West } \\
\hline \multicolumn{10}{|l|}{ 158-957I- } \\
\hline 1N-1, 69-73 (Piece 11) & 9.69 & Intensely silicified basalt breccia, quartz vein net & $\mathrm{SC}$ & $0.704146 \pm 0.000011 \dagger$ & 12 & 7 & 57 & & 13.7 \\
\hline \multicolumn{10}{|l|}{$158-957 \mathrm{M}-$} \\
\hline 3R-1, 19-21 (Piece 5) & 14.49 & Silicified basalt clast, $<5 \%$ quartz + pyrite veins & $\mathrm{SC}$ & $0.703935 \pm 0.000010 \dagger$ & 34 & 40 & 116 & & 10.7 \\
\hline 5R-1, 22-24 (Piece 6) & 24.52 & Silicified wallrock breccia, intensely silicified, quartz vein net & Wbx & $0.703991 \pm 0.000010 \dagger$ & 19 & 13 & 67 & & 8.7 \\
\hline 7R-1, 24-27 (Piece 5) & 34.54 & Paragonitized basalt, $10 \%$ pyrite (+ quartz) veins & $\mathrm{Pbx}$ & $0.703937 \pm 0.000010 \dagger$ & 54 & 39 & 71 & & 8.2 \\
\hline 9R-1, 32-37 (Piece 6, gray) & 42.62 & Dark gray host basalt & G & $0.702646 \pm 0.000010 \dagger$ & 98 & 111 & 111 & 5.9 & \\
\hline 9R-1, 32-37 (Piece 6, green) & 42.62 & Green chloritized alteration halo & $\mathrm{C}$ & $0.703342 \pm 0.000010 \dagger$ & 110 & 62 & 55 & 4.5 & \\
\hline 10R-1, 30-32 (Piece 5) & 46.50 & Dark gray basalt & G & $0.702609 \pm 0.000010$ & 99 & 118 & 117 & 6.7 & \\
\hline 10R-1, 33-36 (Piece 6) & 46.53 & Dark gray basalt, shipboard XRF powder & G & $0.702692 \pm 0.000008 \dagger$ & 98 & 124 & 124 & 6.8 & \\
\hline & 47.70 & Dark gray basalt & G & $0.702728 \pm 0.000010 \dagger$ & 100 & 117 & 115 & 6.4 & \\
\hline 10R-1, 142-143 (Piece21, green) & 47.70 & Green chloritized alteration halo & $\mathrm{C}$ & & 107 & 144 & 132 & 5.2 & \\
\hline 10R-2, 17-19 (Piece 3, gray) & 47.83 & Dark gray basalt & G & $0.702714 \pm 0.000010 \dagger$ & 99 & 118 & 117 & & \\
\hline 10R-2, 17-19 (Piece 3, green) & 47.83 & Green chloritized alteration halo & $\mathrm{C}$ & $0.703293 \pm 0.000010 \dagger$ & 110 & 77 & 69 & & \\
\hline \multicolumn{10}{|l|}{ TAG-5 North } \\
\hline \multicolumn{10}{|c|}{ Silicified wallrock brecci intensely silicified ourtz + nvrite vein net } \\
\hline 8R-1, 5-7 (Piece 2) & 35.15 & Silicified wallrock breccia, intensely silicified, quartz + pyrite vein net & Wbx & $0.703919 \pm 0.000011 \dagger$ & 22 & 15 & 67 & & 8.1 \\
\hline 10R-1, 3-4 (Piece 1) & 45.13 & Silicified basaltic clast & $\mathrm{SC}$ & $0.704063 \pm 0.000014 \dagger$ & 19 & 15 & 8 & & 8.8 \\
\hline 12R-2, 15-19 (Piece 4) & 55.79 & Silicified basalt, no visible veins & $\mathrm{SC}$ & $0.704000 \pm 0.000010 \dagger$ & 52 & 41 & 78 & & $8.8,9.0$ \\
\hline $12 \mathrm{R}-4,38-40$ (Piece 2) & 57.51 & Intensely silicified basalt, quartz + pyrite vein net & $\mathrm{SC}$ & $0.705579 \pm 0.000010 \dagger$ & 36 & 39 & 107 & & \\
\hline
\end{tabular}

Notes: Sample classification and abbreviations as in Table 1. Depth (mbsf) relative to the top of each individual hole. $\dagger=$ samples analyzed for ${ }^{87}$ Sr ${ }^{8}{ }^{8}$ Sr in 1996 ; others were samples analyzed in 1995 . See text for details of standardization. $\delta^{18} \mathrm{O}$ analyses shown are a subset of data presented in Alt and Teagle (Chap. 21 , this volume). $\mathrm{Sr}, \mathrm{Zr}$ concentrations are after Humphris et al. (Chap. 19 , this volume). $\mathrm{Sr}^{*}=$ normalized strontium concentration, where $\mathrm{Sr} *=[\mathrm{Sr}] \times$ $[\mathrm{Zr}] \mathrm{ave} /[\mathrm{Zr}]$; [Zr] ave is the average $\mathrm{Zr}$ concentration of gray basalts recovered from the TAG mound $(\approx 98 \mathrm{ppm})$. WR $=$ whole rock. 


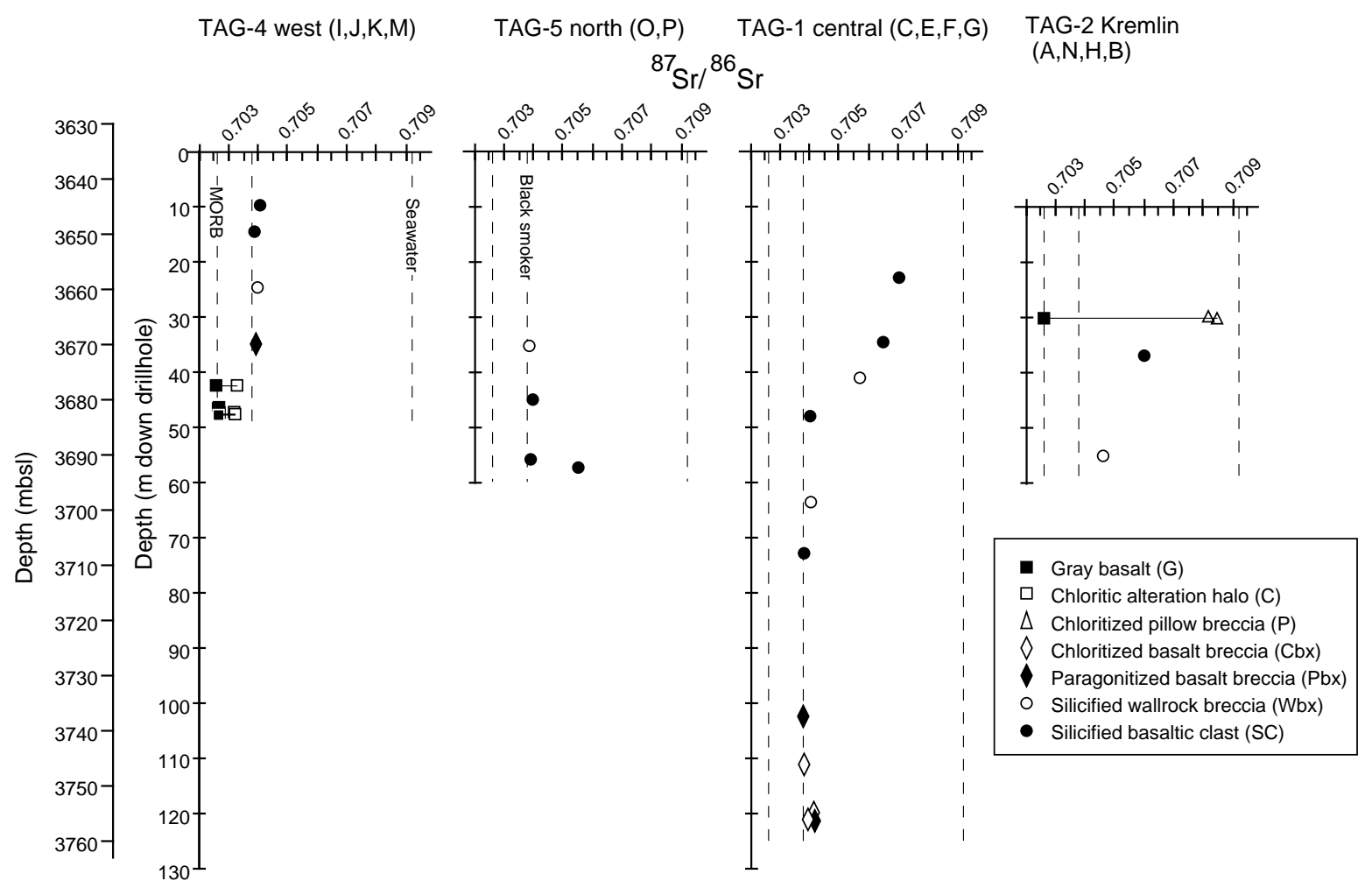

Figure 4. Strontium-isotopic compositions vs. depths for whole-rock samples from TAG-1, TAG-2, TAG-4, and TAG-5. The top of the profiles for TAG-1, TAG-4, and TAG-5 are placed at a depth of 3635 meters below sea level (mbsl). The top of the TAG-2 penetration is located at 3645 mbsl. Rock classification as in Table 1.

outlined in Alt and Teagle (Chap. 21, this volume). Results are reported in Table 2 as $\delta$ notation relative to standard mean ocean water (SMOW; Craig, 1961).

\section{RESULTS AND DISCUSSION}

The strontium- and oxygen-isotopic results presented in this study must be interpreted in terms of the paragenetic information available from petrographic descriptions and the mineralogy and sequence of basalt alteration. However, the different potential end-member fluids (Campbell et al., 1988; Elderfield et al., 1993; Edmond, et al., 1995), both hydrothermal and seawater, and the complications caused by the fluid mixing, and conductive heating or cooling (e.g., Janecky and Seyfried, 1984; Ridley et al., 1994) must also be accounted for. The rigorous modeling of fluid-rock tracer exchange during either channeled or porous media flow through altered or relatively fresh rocks requires knowledge of an appropriate fluid-rock partition coefficient for the particular tracer of interest (e.g., Sr, O; Bickle and Teagle, 1992). However, these parameters are difficult to estimate in situations where the concentrations of the tracers can vary in both the fluid and the rock. For the qualitative purposes of this study, a fluid-rock partition coefficient of 1 has been assumed for all tracers throughout the following mixing calculations.

It is important that the isotopic signatures of possible end-member fluids are well constrained. The ${ }^{87} \mathrm{Sr} /{ }^{86} \mathrm{Sr}$ of modern seawater is well established ${ }^{87} \mathrm{Sr} /{ }^{86} \mathrm{Sr} \approx 0.70918$, Hodell et al., 1991), but there is some dispute as to the strontium-isotopic composition of end-member black smoker effluents that issue from the TAG hydrothermal mound. Measurements of highly diluted hydrothermal fluids ( $\geq 90 \%$ seawater) from black smoker seeps extrapolate to an end-member ${ }^{87} \mathrm{Sr} /{ }^{86} \mathrm{Sr}$ ratio of 0.7029 (Campbell et al., 1988). A compilation of un- published strontium-isotopic data for black smokers from the TAG mound plotted vs. Mg concentration extrapolates to an end-member ratio of approximately 0.7035 (Elderfield et al., 1993), but workers from this group appear to prefer an extrapolation that utilizes data from both black and white smoker fluids and suggest a ${ }^{87} \mathrm{Sr} /{ }^{86} \mathrm{Sr}$ ratio of 0.70319 (e.g., James et al., 1995; Mills and Elderfield, 1995). Less diluted hydrothermal fluid samples collected from the TAG black smokers in 1990 yield an end-member ${ }^{87} \mathrm{Sr} /{ }^{86} \mathrm{Sr}$ of 0.7038 (Edmond et al., 1995). Data presented in the following sections strongly support the latter measurement as the correct value for end-member fluid strontium-isotopic composition. A $\delta^{18} \mathrm{O}$ of $\approx 1.7 \%$ or end-member black smoker fluids has been recently determined by Shanks et al. (1995).

Strontium- and oxygen-isotopic compositions and strontium contents for whole-rock samples from Site 957 are presented in Table 2, and ${ }^{87} \mathrm{Sr} /{ }^{86} \mathrm{Sr}$ ratios are plotted vs. depth for each of the drilling areas in Figure 4. Also presented in Table 2 are $\delta^{18} \mathrm{O}$ determinations of quartz mineral separates from samples for which ${ }^{87} \mathrm{Sr} /{ }^{86} \mathrm{Sr}$ have been measured on the bulk-rock powder. This is a subset of the data reported by Alt and Teagle (Chap. 21, this volume). Samples have been classified into one of seven alteration categories, described in Table 1.

Gray basalts, recovered at TAG- 2 and TAG- 4 , have low ${ }^{87} \mathrm{Sr} /{ }^{86} \mathrm{Sr}$ ratios $(0.7026-0.7027$; average $=0.70265, n=6)$. These samples contain only minor amounts (5\% to $15 \%$ ) of secondary minerals, predominantly saponite. The presence of fresh olivine in some samples attests to their relative freshness. Although no leaching experiments have been conducted on these samples, the generally low strontium contents of saponite (e.g., Teagle et al., 1996), and the only minor proportions of these phases suggest that the primary ${ }^{87} \mathrm{Sr} /{ }^{86} \mathrm{Sr}$ of TAG basalts is around 0.7026. A previous study (Campbell et al., 1988) estimated this ratio to be 0.7029 , though direct measurements of basalts were not undertaken. 
Chloritic alteration halos (TAG-4), developed along the rims of basaltic clasts, have slightly elevated ${ }^{87} \mathrm{Sr} /{ }^{86} \mathrm{Sr}$ compositions $(0.7033)$ compared to the neighboring gray basalts, indicating the partial replacement of igneous minerals and filling of interstices by secondary phases enriched in seawater-derived strontium. Chloritized pillow breccias (TAG-2), by contrast, have highly elevated ${ }^{87} \mathrm{Sr} /{ }^{86} \mathrm{Sr}$ (0.7082-0.7084), close to the strontium-isotopic composition of seawater. These samples are completely recrystallized to secondary minerals and hence the measured ratio must be close to that of the reacting fluid.

Perhaps the most striking feature of Figure 4 is the abundance of samples with ${ }^{87} \mathrm{Sr} /{ }^{86} \mathrm{Sr}$ ratios in the range 0.7038 to 0.7042 at moderate depths in the stockwork zone. No samples of hydrothermal assemblages have ${ }^{87} \mathrm{Sr} /{ }^{86} \mathrm{Sr}<0.7038$. This strongly suggests that upwelling hydrothermal fluids had a ${ }^{87} \mathrm{Sr} /{ }^{86} \mathrm{Sr}$ of approximately 0.7038 . This estimate agrees closely with recently published measurements of end-member fluids from the central Black Smoker Complex at TAG (Edmond et al., 1995), and there is no evidence for fluids with lower ${ }^{87} \mathrm{Sr} /{ }^{86} \mathrm{Sr}$. Hydrothermal assemblages with elevated ${ }^{87} \mathrm{Sr} /{ }^{86} \mathrm{Sr}$ may reflect variable but generally minor mixing with seawater, but mixing calculations presented in a following section indicate contamination by late-stage anhydrite.

The relative extent of alteration by hydrothermal fluids vs. seawater and the mixing of these two components is addressed in Figures 5 and 6. Measured whole-rock strontium concentrations (after Humphris et al., Chap. 19, this volume) are plotted vs. ${ }^{87} \mathrm{Sr} /{ }^{86} \mathrm{Sr}$ (Fig. $5 \mathrm{~A})$. Tie lines join different alteration types separated from the same sample. Mixing lines, delineating simple strontium exchange between fresh TAG basalt (Sr: $117 \mathrm{ppm} ;{ }^{87} \mathrm{Sr} /{ }^{86} \mathrm{Sr}$ : 0.7026), seawater (Sr: $7.6 \mathrm{ppm} ;{ }^{87} \mathrm{Sr} /{ }^{86} \mathrm{Sr}$ : 0.70917; Hodell et al., 1991) and end-member black smoker fluids (Sr: 9 ppm; ${ }^{87} \mathrm{Sr} /{ }^{86} \mathrm{Sr}$ : 0.7038; Edmond et al., 1995) are displayed.

Many hydrothermal assemblages from the TAG deposit are highly silicified, pyritized, and/or hydrated, because of the disruption and replacement of the original basalt wallrock by brecciation, mineralization, and multiple veining events. In order to account for the effects of this dilution, the measured strontium concentrations have been normalized with respect to measured $\mathrm{Zr}$ contents relative to that of fresh TAG basalt, and plotted vs. ${ }^{87} \mathrm{Sr} /{ }^{86} \mathrm{Sr}$ (Fig. 5B). The strong linear correlation between immobile element concentrations (e.g., $\mathrm{Zr}$, $\mathrm{Y}, \mathrm{TiO}_{2}$, rare earth elements) for all rock types recovered from the TAG mound (see Humphris et al., Chap. 19, this volume) indicates, that for these elements, changes in concentration are predominantly due to dilution by quartz and pyrite, and supports the validity of this simplistic approach to assess the mobility of strontium.

Whole-rock strontium- and oxygen-isotopic compositions of relatively fresh and altered basalts are plotted in Figure 6A. In Figure 6B the isotopic behaviors of alteration assemblages from the mineralized stockwork are assessed and whole-rock ${ }^{87} \mathrm{Sr} /{ }^{86} \mathrm{Sr}$ is plotted vs. $\delta^{18} \mathrm{O}$ for quartz separated from these samples. The strontium content of quartz is extremely low, with strontium in these samples present in minor concentrations in paragonite, chlorite, relict igneous phases, or captured fluid inclusions. It is assumed that quartz is both in oxygenand strontium-isotopic equilibrium with the other phases that comprise the samples from which grains have been separated.

The tight clustering of analyses of gray basalts in Figures 5 and 6 supports the suggestion that these rocks have near primary strontium contents and isotopic compositions. $\delta^{18} \mathrm{O}$ of the gray basalts are in the range from $5.9 \%$ o to $6.8 \%$, identical or slightly enriched compared to primary oxygen isotope signature of fresh MORB of $5.7 \% \circ \pm 0.3 \%$ o
A

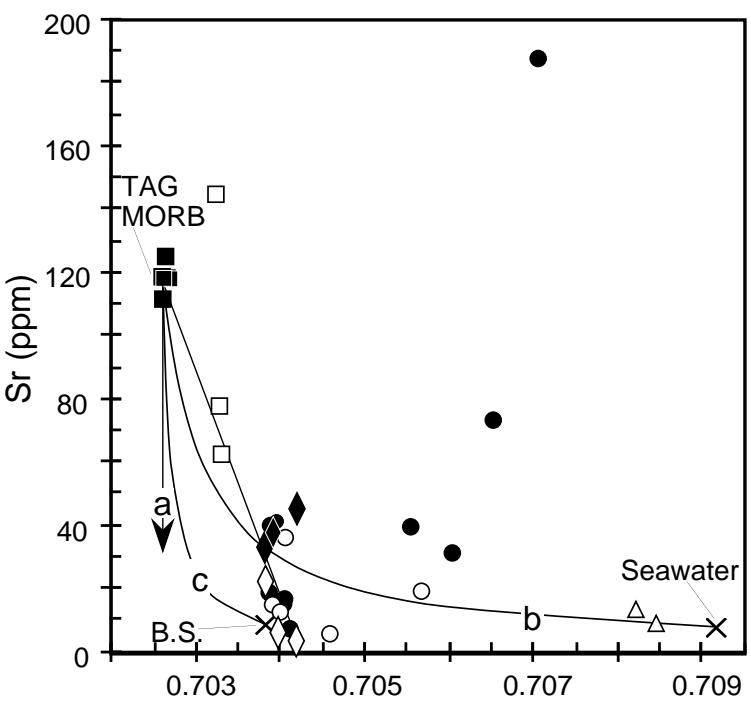

B

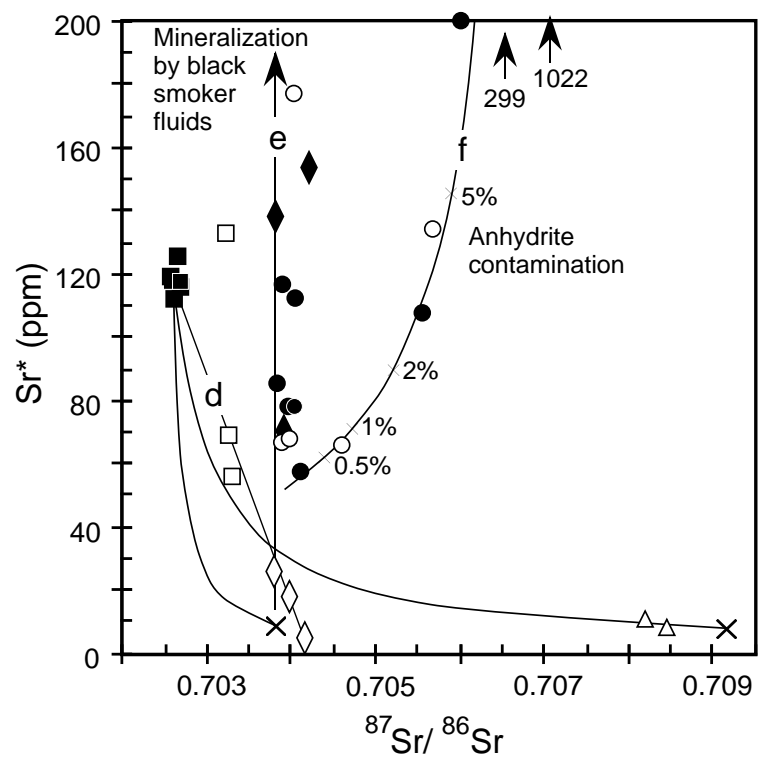

Figure 5. A. Measured ${ }^{87} \mathrm{Sr} /{ }^{86} \mathrm{Sr}$ plotted vs. strontium concentrations for whole-rock samples from the TAG hydrothermal mound. B. ${ }^{87} \mathrm{Sr} /{ }^{86} \mathrm{Sr}$ vs. normalized strontium concentrations (see Table 2). Symbols are as in Figure 4. Solid lines show different mixing and fluid-rock interaction trajectories. Path $\mathbf{a}=$ dissolution of $\mathrm{Sr}$ from basalt with negligible precipitation of fluid $\mathrm{Sr}$. Path $\mathbf{b}=$ simple mixing between seawater $\left({ }^{87} \mathrm{Sr} /{ }^{86} \mathrm{Sr} \approx 0.70918,[\mathrm{Sr}] \pm 7.6 \mathrm{ppm}\right)$ and pristine TAG MORB $\left({ }^{87} \mathrm{Sr} /{ }^{86} \mathrm{Sr} \approx 0.7026,[\mathrm{Sr}] \approx 117 \mathrm{ppm}\right)$. Path $\mathbf{c}=$ simple mixing between pristine TAG MORB and end-member TAG black smoker fluid $\left({ }^{87} \mathrm{Sr} /{ }^{86} \mathrm{Sr} \approx\right.$ 0.7038, [Sr] $\approx 9$ ppm; this study; Edmond et al., 1995). Path $\mathbf{d}=$ interaction between TAG basalt and a precursor high-temperature, Mg-rich, hydrothermal fluid $\left({ }^{87} \mathrm{Sr} /{ }^{86} \mathrm{Sr} \approx 0.7042,[\mathrm{Sr}] \approx 10 \mathrm{ppm}\right)$ where the dissolution of basaltic $\mathrm{Sr}$ is much greater than reprecipitation from the fluid. The elevated ${ }^{87} \mathrm{Sr} /{ }^{86} \mathrm{Sr}$ ratio compared to end-member black smoker fluids and the high $\mathrm{Mg}$ content reflect the presence of a minor seawater component in the hydrothermal fluid. This is required to explain the high magnesium contents of the chloritized alteration halos and chloritized basalt breccias that appear to be necessary precursors to the main stage of mineralization and silicification in the TAG mound and stockwork. Path $\mathbf{e}=$ mineralization by large fluxes of TAG black smoker fluids. Chloritized basalt breccias are silicified, pyritized, and paragonitized with concomitant Sr enrichment and loss of Mg. Path $\mathbf{f}=$ mixing line showing the percentage contamination of an arbitrary hydrothermal assemblage by an average anhydrite from the TAG mound $\left({ }^{87} \mathrm{Sr} /{ }^{86} \mathrm{Sr} \approx 0.7069\right.$, [Sr] $\approx 1894 \mathrm{ppm}$; see Teagle et al., Chap. 11 , this volume). Percentage contamination is shown. 

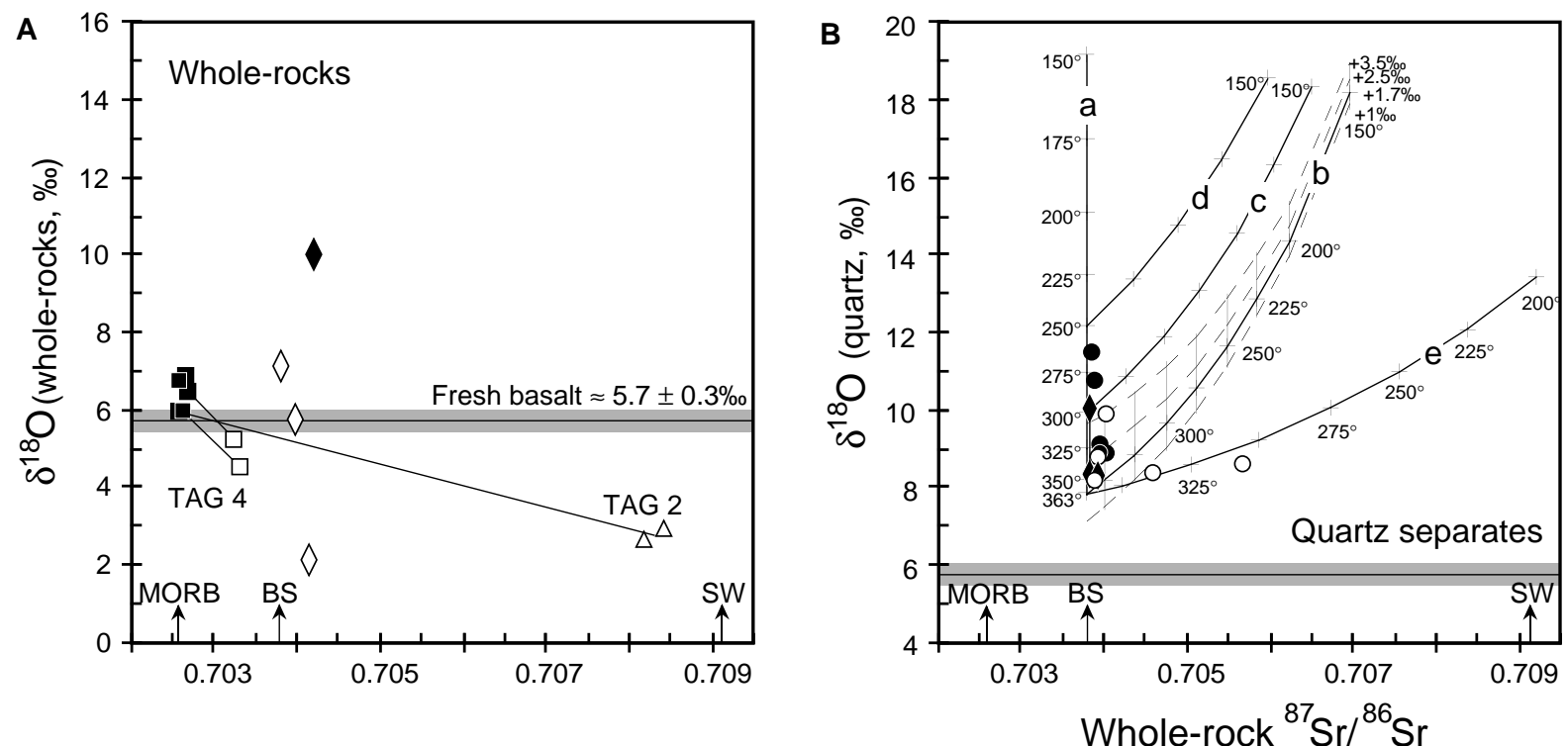

Figure 6. A. Whole-rock ${ }^{87} \mathrm{Sr} /{ }^{86} \mathrm{Sr}$ vs. $\delta^{18} \mathrm{O}$ for altered basalts and chloritized and paragonitized alteration assemblages from the TAG mound. Tie lines join juxtaposed samples. The stippled region delineates the range of $\delta^{18} \mathrm{O}$ for fresh basalts $\left(\delta^{18} \mathrm{O} \approx 5.7 \%\right.$. $\pm 0.3 \%$; Gregory and Taylor, 1981). The ${ }^{87} \mathrm{Sr} /{ }^{86} \mathrm{Sr}$ of TAG MORB, black smoker fluids, and modern seawater are marked. Symbols as in Figure 4 . B. Whole-rock ${ }^{87} \mathrm{Sr} /{ }^{86} \mathrm{Sr}$ vs. $\delta^{18} \mathrm{O}$ of quartz separates from hydrothermal assemblages from the TAG mound. It is assumed that the ${ }^{87} \mathrm{Sr} /{ }^{86} \mathrm{Sr}$ ratio of minor $\mathrm{Sr}$-bearing hydrothermal phases records the Sr-isotopic composition of the fluid from which these minerals and quartz precipitated and that all phases have remained in $\mathrm{Sr}$ - and oxygen-isotopic equilibrium. Solid lines show possible isotopic evolution trajectories resulting from fluid mixing and/or conductive heating or cooling of hydrothermal fluid or seawater. The lines trace the $\delta^{18} \mathrm{O}$ of quartz precipitated from these fluid mixtures and the ${ }^{87} \mathrm{Sr} /{ }^{86} \mathrm{Sr}$ of the fluid mixture. Path $\mathbf{a}=$ conductive cooling of end-member black smoker fluid $\left(\mathrm{T}=363^{\circ} \mathrm{C} ;{ }^{87} \mathrm{Sr} /\right.$ ${ }^{86} \mathrm{Sr} \approx 0.7038$; this study; Edmond et al., $1995 ; \delta^{18} \mathrm{O} \approx 1.7 \%$; Shanks et al., 1995). Path $\mathbf{b}=$ simple mixing between black smoker fluid and ambient seawater (T $=0{ }^{\circ} \mathrm{C} ;{ }^{87} \mathrm{Sr} /{ }^{86} \mathrm{Sr} \approx 0.70918 ; \delta^{18} \mathrm{O} \approx 0 \%$ ). Adjacent dashed lines show the mixing for hydrothermal fluids with a range of oxygen-isotopic compositions $\left(\delta^{18} \mathrm{O}=\right.$ $1 \%, 2.5 \%$, and $3.5 \%$ o). Path $\mathbf{c}=$ mixing line between ambient seawater and a black smoker fluid that has been conductively cooled to $300^{\circ} \mathrm{C}$ before mixing. Path $\mathbf{d}=$ mixing line between ambient seawater and a black smoker fluid that has been conductively cooled to $250^{\circ} \mathrm{C}$ before mixing. Path $\mathbf{e}=$ mixing line between a black smoker fluid $\left(\mathrm{T}=363^{\circ} \mathrm{C}\right)$ and seawater that has been conductively heated to $200^{\circ} \mathrm{C}$ before mixing. Vertical arrows show the ${ }^{87} \mathrm{Sr} /{ }^{86} \mathrm{Sr}$ composition of MORB, end-member black smoker fluid (BS), and seawater (SW). Quartz-water ${ }^{18} \mathrm{O}$ fractionation uses the recent calibration of Sharp and Kirshner (1994).

(Gregory and Taylor, 1981). The minor proportions of smectite in these samples $(5 \%-15 \%)$ require highly elevated $\delta^{18} \mathrm{O}$ for secondary clays in order to explain the slight enrichment in whole-rock $\delta^{18} \mathrm{O}$ in some samples, implying alteration at low temperatures $\left(<100^{\circ} \mathrm{C}\right.$, Alt and Teagle, Chap. 21, this volume; Muehlenbachs and Clayton, 1972; Savin and Lee, 1988). Chloritic alteration halos associated with some of the gray basalts can be both slightly enriched or moderately depleted in their strontium contents and have slightly higher ${ }^{87} \mathrm{Sr} /{ }^{86} \mathrm{Sr}$. Depleted whole-rock $\delta^{18} \mathrm{O}$ values $\left(4.2 \%{ }^{-}-5.2 \% o\right)$, compared to fresh MORB as well as the gray basalts indicate that these halos formed by interaction with fluids at temperatures $>200^{\circ} \mathrm{C}$. All three samples lie above the ${ }^{87} \mathrm{Sr} /{ }^{86} \mathrm{Sr}-\mathrm{Sr}$ mixing lines between fresh basalt and seawater or hydrothermal fluid (Fig. 5). This alteration could be the result of interaction with either conductively heated seawater or a Mg-bearing, hydrothermal fluid. Petrographic observations indicate that approximately $50 \%$ of the primary plagioclase in these halos is broken down to secondary phases. As plagioclase contains the bulk of the igneous strontium, and glass and mesostasis are more susceptible to hydrothermal alteration, the shift in the bulk rock ${ }^{87} \mathrm{Sr} /{ }^{86} \mathrm{Sr}$ to 0.7032 , approximately midway between fresh MORB and the TAG hydrothermal end-member strongly suggests that these samples were altered by hydrothermal fluids, rather than conductively heated seawater. The chloritized halos are enriched in $\mathrm{Zn}$ and $\mathrm{S}$ (Humphris et al., Chap. 19, this volume) and contain Fe chlorite (chamosite: J. Alt, unpubl. data) consistent with this interpretation.

Path d (Fig. 5B) shows the trajectory for fresh basalt altered by a Mg-bearing hydrothermal fluid $\left({ }^{87} \mathrm{Sr} /{ }^{86} \mathrm{Sr} \approx 0.7042\right)$ with a minor $(<10 \%)$ seawater component, where the dissolution of basaltic $\mathrm{Sr}$ is much greater than $\mathrm{Sr}$ reprecipitation from the fluid. This vector passes through the analyses of chloritic alteration halos to data for chloritized basalt breccias. This suggests that the former rock type may represent an intermediate between fresh basalt and the chloritized breccias and that both these chlorite-rich assemblages were altered by a similar hydrothermal fluid (Mg-bearing, $<10 \%$ seawater, ${ }^{87} \mathrm{Sr} /{ }^{86} \mathrm{Sr} \approx 0.7038-0.7042$ ).

Two samples of chloritized pillow breccias have been analyzed from TAG-2 (Hole 957B). These samples are completely recrystallized to chlorite and are highly enriched in magnesium, and the basalt clast is stained red by late-stage hematite. Strontium concentrations are strongly depleted (9 and $13 \mathrm{ppm}$ ) and yield seawater-like ${ }^{87} \mathrm{Sr} /{ }^{86} \mathrm{Sr}$ ratios, which lie on the simple mixing line between fresh TAG basalt and seawater (Fig. 5A, B). Low $\delta^{18} \mathrm{O}(2.6 \%$ and $2.9 \%$; Fig. 6) values indicate that fluid-rock interaction and recrystallization took place at elevated temperatures, at least $210^{\circ}-250^{\circ} \mathrm{C}$ (Alt and Teagle, Chap. 21 , this volume). The low $\delta^{18} \mathrm{O}$, near-seawater ${ }^{87} \mathrm{Sr} /{ }^{86} \mathrm{Sr}$ ratios, and bulk-rock gains of $\mathrm{Mg}$ (Humphris et al., Chap. 19, this volume) of these samples provide compelling evidence for presence of conductively heated seawater beneath the margins of the mound. The high ${ }^{87} \mathrm{Sr} /{ }^{86} \mathrm{Sr}$ ratio implies very large seawater fluxes and that seawater was heated to $250^{\circ} \mathrm{C}$ without mixing with other hydrothermal fluids or had no significant interaction with basalt until encountering the pillow margin breccias.

Most samples of hydrothermal assemblages cluster around a strontium-isotopic composition of 0.704 , with strontium concentrations much lower than fresh MORB, but relatively high compared with end-member black smoker fluids (Fig. 5A). This relative stron- 
tium enrichment of the rocks is accentuated if the dilution effects of silicification and mineralization are taken into account (Fig. 5B)

Petrographic relationships indicate that chloritized basalt and breccias are replaced by the paragonite + quartz + pyrite assemblages of the silicified wallrock breccias. The chlorite + pyrite + quartz alteration assemblage was observed only in the deepest part of the stockwork at TAG-1, and paragonite-bearing assemblages (silicified basalt and wallrock breccias) overprint chloritic alteration along vein margins. Chloritized breccias are enriched in $\mathrm{Mg}$ (Humphris et al., Chap. 19, this volume), depleted in $\mathrm{Sr}$ (Fig. 5A, B), and have ${ }^{87} \mathrm{Sr} /{ }^{86} \mathrm{Sr}$ ratios of 0.7038 to 0.7042 , only slightly higher than end-member black smoker fluids (0.7038). $\delta^{18} \mathrm{O}$ of quartz and chlorite from these rocks indicate temperatures of $250^{\circ}$ to $350^{\circ} \mathrm{C}$ for fluid-rock interaction in the deepest levels of the TAG stockwork. (Alt and Teagle, Chap. 21, this volume). Chloritized breccia samples fall along Path $\mathbf{d}$ of Figure $5 \mathrm{~B}$ that traces a trajectory of interaction between fresh MORB and a fluid where dissolution of Sr-bearing phases is much greater than reprecipitation of secondary phases with low Sr contents. This suggests that these rocks formed by interaction with a hot hydrothermal fluid with a minor seawater component $\left({ }^{87} \mathrm{Sr} /{ }^{86} \mathrm{Sr} \approx 0.7042\right)$, which is responsible for the high $\mathrm{Mg}$ contents of these samples. The occurrence of Mg-rich assemblages and the initial chloritization of the stockwork zone agrees with thermodynamic predictions based on modeling the mixing of seawater and black smoker fluids (Janecky and Seyfried, 1984).

When normalized to primary $\mathrm{Zr}$ contents, the undiluted $\mathrm{Sr}$ contents of paragonitized basalt breccias, silicified wallrock breccia and silicified basaltic clasts, range from 60 to 180 ppm, suggesting moderate depletion to enrichment of $\mathrm{Sr}$ in these samples compared to fresh MORB. These hydrothermal assemblages have significantly higher strontium contents than the chloritized basalt breccias found at

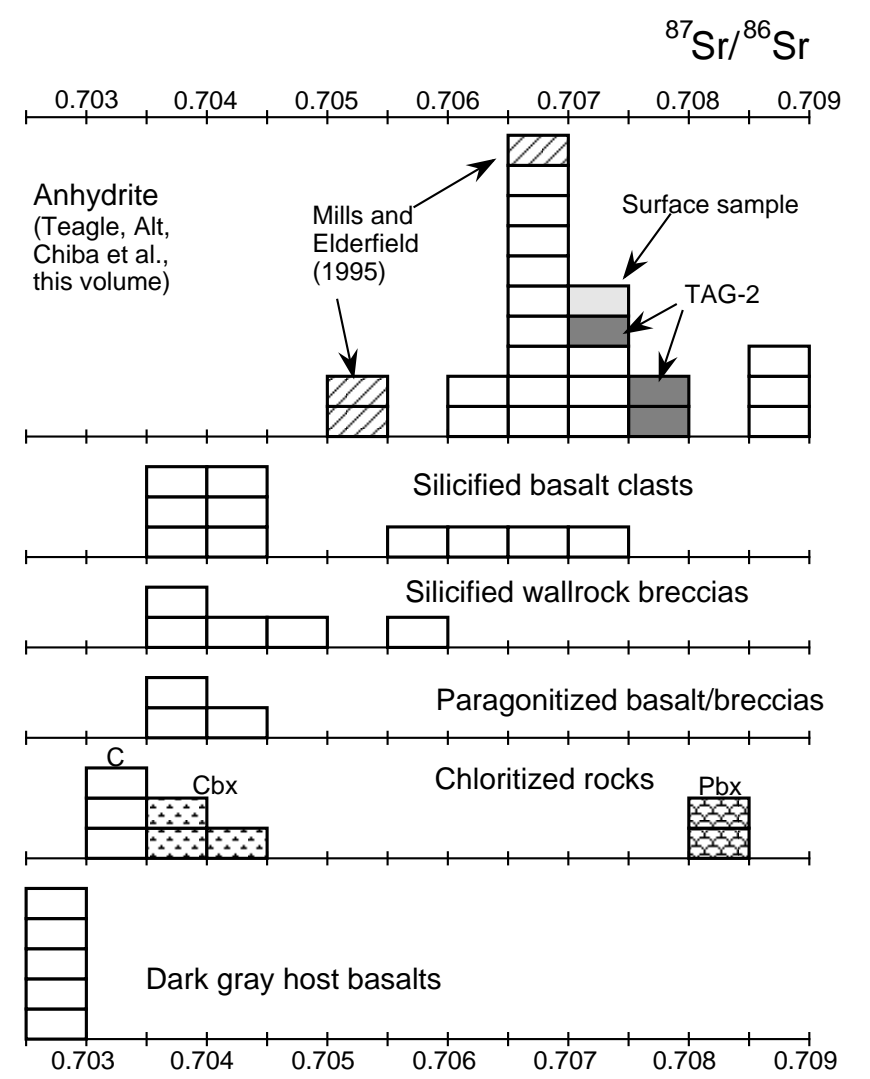

Figure 7. Histogram summarizing the range in ${ }^{87} \mathrm{Sr} /{ }^{86} \mathrm{Sr}$ for the different alteration classifications (anhydrite analyses after Teagle et al., Chap. 11, this volume). the base of the TAG stockwork. The similarity in ${ }^{87} \mathrm{Sr} /{ }^{86} \mathrm{Sr}$ ratios for these rock types and observed petrogenetic relationships implies that the initial hydrothermal fluids were enriched in $\mathrm{Mg}$, but that later fluids, responsible for most of the mineralization in the TAG mound and stockwork, were highly depleted in $\mathrm{Mg}$. The $\mathrm{Sr}$ isotopic-signature of this evolving fluid remained in the range from 0.7038 to 0.7042 . A similar progression from $\mathrm{Mg}$-rich assemblages to $\mathrm{Ca}$-rich, and hence Sr-rich, rock types is observed in the fossil upwelling zones within the sheeted dike complex of the Troodos ophiolite (Richardson et al., 1987; Schiffman et al., 1987). In many epidosite zones, the recrystallization of diabase to $\mathrm{Mg}$-rich, quartz-chlorite-epidote rocks are an ubiquitous and essential precursor to the development of epidosite (Teagle, 1993a, 1993b). The progression from chloritization to Carich assemblages is also preserved in the mineralized stockwork zone of Hole 504B (Alt et al., 1986).

Mixing between hydrothermal fluids and conductively heated seawater is addressed in Figure 6B for the hydrothermal assemblages. These simple mixing lines neglect the changes in fluid heat capacity with temperature, and the effects of the conductive heating or cooling of fluids caused by mixing. It is assumed that if mixing is rapid, these effects will be minor and may partially offset one another (Janecky and Seyfried, 1984).

The $\delta^{18} \mathrm{O}$ analyses for quartz separated from whole-rock samples are plotted vs. the whole-rock ${ }^{87} \mathrm{Sr} /{ }^{86} \mathrm{Sr}$ value, assuming that the latter reflects the strontium-isotopic composition of the fluid from which the quartz precipitated (Fig. 6B). In order to define a frame of reference from which to assess the quartz data, the oxygen-isotopic composition of the quartz precipitate and the ${ }^{87} \mathrm{Sr} /{ }^{86} \mathrm{Sr}$ of the fluid have been calculated for conductively cooled end-member black smoker fluids (Fig. 6B, Path a) and the simple mixing of $363^{\circ} \mathrm{C}$ hydrothermal fluid with ambient seawater (Path $\mathbf{b}$ ). Paths for mixing between conductively cooled hydrothermal fluid and ambient seawater (Paths c and $\mathbf{d}$ ), as well as the effects of fractionation of the hydrothermal fluid, are also shown.

Clearly most quartz samples fall within the $\mathrm{V}$ defined by conductive cooling of hydrothermal fluids and simple mixing with cool seawater, with most analyses clustered tightly against the cooling line for end-member black smoker fluids and generally at high temperatures $\left(>300^{\circ} \mathrm{C}\right)$. The range in $\delta^{18} \mathrm{O}$ implies slight conductive cooling of hydrothermal fluids and minor mixing with cold seawater. The effect of conductively heating seawater (without changing the fluid

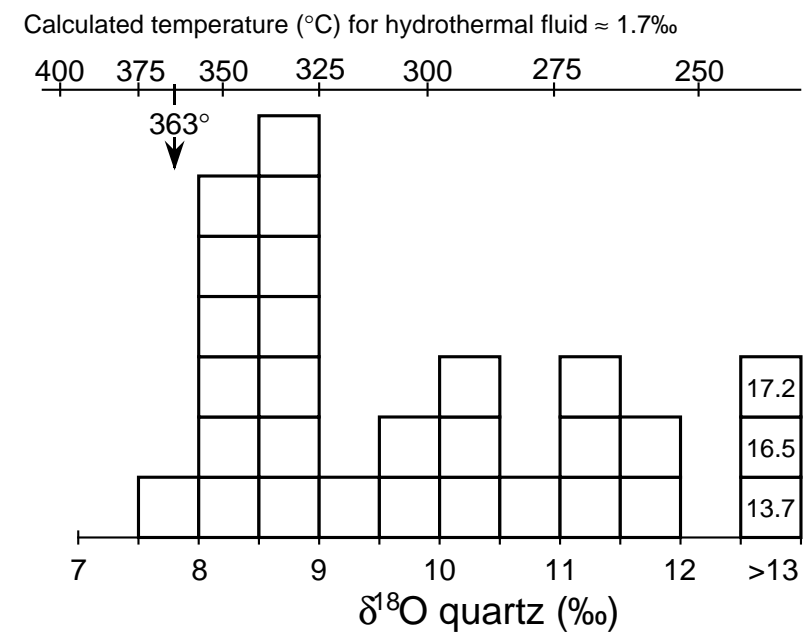

Figure 8. Histogram showing the range in $\delta^{18} \mathrm{O}$ for quartz separates from hydrothermal breccias and silicified rocks from the TAG mound. Additional data to that presented in Table 2 from Alt and Teagle (Chap. 21, this volume). Temperature scale calculated assuming quartz precipitation from an end-member black smoker-like fluid $\left(\delta^{18} \mathrm{O} \approx 1.7 \%\right.$ o using the recent calibration of Sharp and Kirshner (1994). 


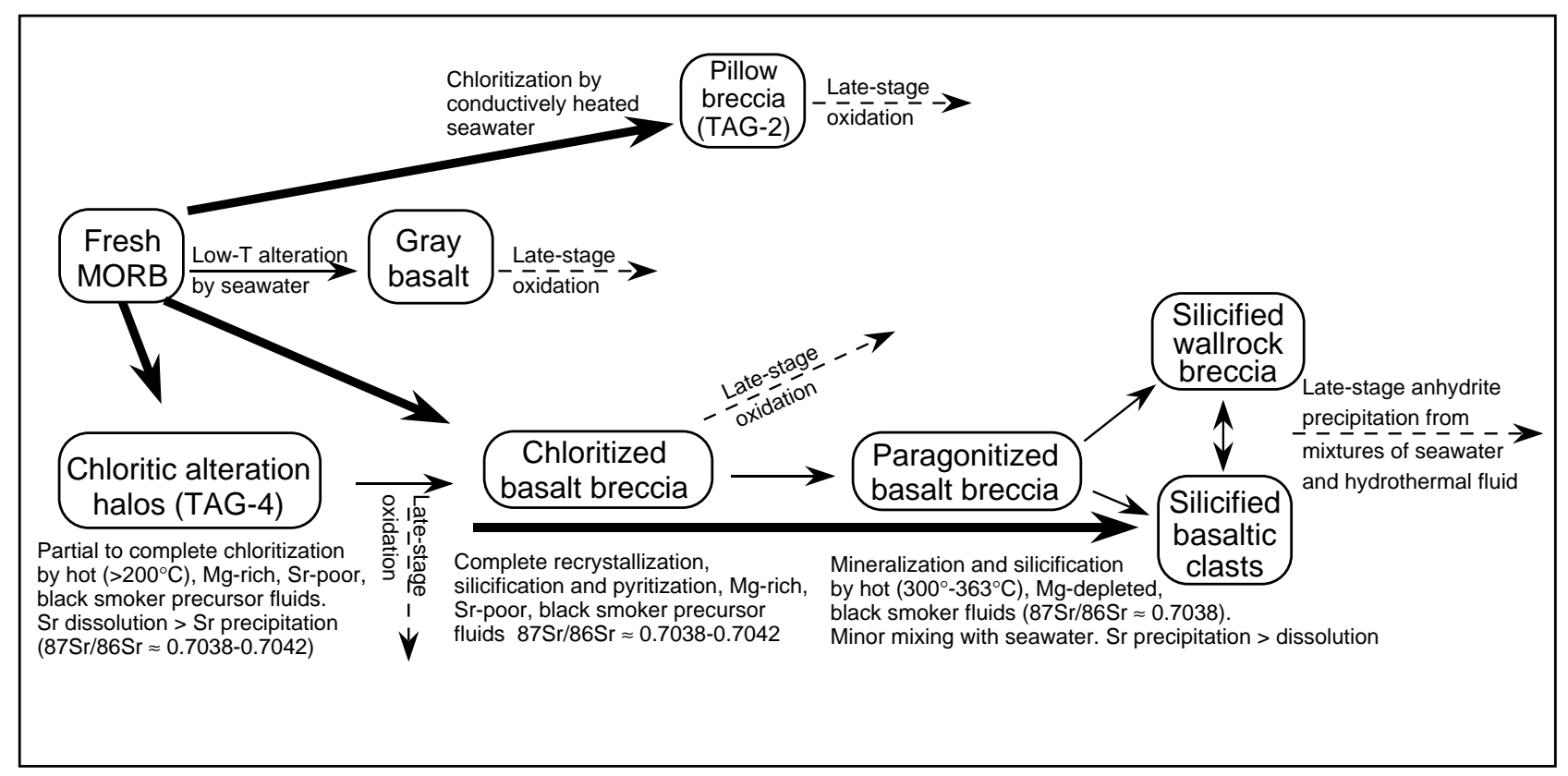

Figure 9. Summary of the alteration and mineralization processes occurring as deduced from petrographic observations, and strontium- and oxygen-isotopic compositions of samples recovered from the TAG hydrothermal mound and stockwork during Leg 158.

$\delta^{18} \mathrm{O}$ or ${ }^{87} \mathrm{Sr} /{ }^{86} \mathrm{Sr}$ ) before mixing is to decrease the gradient on the mixing lines (Fig. 6B, Path e) and unambiguous lines of fluid evolution cannot be resolved if both conductive heating/cooling and mixing occur. However, for the samples of alteration assemblages from the TAG mound, the narrow range of ${ }^{87} \mathrm{Sr} /{ }^{86} \mathrm{Sr}$ ratios suggests that there is only minor $(<10 \%)$ involvement of seawater during mineralization.

A few samples of silicified hydrothermal breccias from the TAG mound and stockwork project to extremely high normalized $\mathrm{Sr}$ contents in Figure 5B. These samples also tend to have elevated ${ }^{87} \mathrm{Sr} /{ }^{86} \mathrm{Sr}$ ratios compared with black smoker fluids, strongly suggesting contamination by a strontium-bearing phase with a near seawater-like strontium isotopic composition. Late-stage anhydrite veins are common throughout the TAG mound, and anhydrite is definitely present in some of the breccias analyzed (e.g., Sample 158-957C-7N-3, 47$49 \mathrm{~cm}$, Piece 4A). A mixing line showing a possible trajectory of $\mathrm{Sr}$ contents and ${ }^{87} \mathrm{Sr} /{ }^{86} \mathrm{Sr}$ ratios caused by the presence of minor amounts of late-stage anhydrite (average of Teagle et al., Chap. 11, this volume) in a hydrothermal breccia is shown in Figure 5B and provides a reasonable explanation for anomalously high ${ }^{87} \mathrm{Sr} /{ }^{86} \mathrm{Sr}$ signatures in a number of samples from the TAG mound.

The swath of low, measured conductive heat flow across the western shoulder of the TAG mound (Becker and Von Herzen, 1996) suggests that there is active entrainment of seawater into the mound in this region. The absence of anhydrite (Humphris, Herzig, Miller, et al., 1996) in the TAG-4 drill holes (Holes 957I, 957J, 957K, and 957M) implies that the subsurface of the mound and stockwork in this area is relatively cool and below $150^{\circ} \mathrm{C}$, the temperature at which extensive precipitation of anhydrite from seawater would be expected (e.g., Bischoff and Seyfried, 1978). Hydrothermal assemblages from the stockwork at TAG-4 yield a restricted range of ${ }^{87} \mathrm{Sr} /{ }^{86} \mathrm{Sr}$ (0.7039-0.7041) similar to stockwork samples from areas of high heat flow, active venting, and abundant anhydrite precipitation. The consistency of this ratio for hydrothermal assemblages across the mound requires that the ${ }^{87} \mathrm{Sr} /{ }^{86} \mathrm{Sr}$ ratio of end-member hydrothermal fluids has remained constant for a time period longer than that re- quired to change the interior thermal structure and plumbing network of the mound and underlying stockwork.

\section{CONCLUSIONS}

Strontium- and oxygen-isotopic compositions of whole-rock samples and quartz separates, combined with petrographic observations provide important constraints on the physical and chemical nature of fluid-rock interactions during alteration of basalt and sulfide mineralization in the active TAG hydrothermal deposit. The ranges of measured ${ }^{87} \mathrm{Sr} /{ }^{86} \mathrm{Sr}$ ratios for different rock types from the TAG mound and underlying stockwork zone are shown in Figure $7 . \delta^{18} \mathrm{O}$ analyses of quartz separates from hydrothermal breccias from the TAG deposit are summarized in Figure 8. Temperatures have been calculated using the fractionation equation for quartz of Sharp and Kishner $(1994)$, assuming equilibrium with a black smoker-type fluid with $\delta^{18} \mathrm{O} \approx 1.7 \%$.

Fresh MORB, with a ${ }^{87} \mathrm{Sr} /{ }^{86} \mathrm{Sr}$ of 0.7026 , from the basement beneath of the TAG mound was altered at both low and high temperatures by seawater and altered at high temperature by near end-member hydrothermal fluids. Pillow breccias occur beneath the margins of the hydrothermal mound in Hole 957B (TAG-2). These rocks were completely recrystallized to chlorite by interaction with conductively heated seawater $\left(>200^{\circ} \mathrm{C}\right)$, and ${ }^{87} \mathrm{Sr} /{ }^{86} \mathrm{Sr}$ ratios $(0.7082,0.7085)$ near seawater imply that large volumes of seawater were conductively heated to $>250^{\circ} \mathrm{C}$ without prior interaction with basalt or mixing with hydrothermal fluids.

The conditions and processes responsible for the alteration of the host basalt and sulfide and quartz mineralization of the TAG stockwork are summarized by a simple paragenetic sequence in Figure 9. The initial high-temperature interaction and alteration in the TAG basement involved the development of chloritic alteration halos around the rims of basaltic clasts. The halos are enriched in $\mathrm{Zn}$ and S, and contain $\mathrm{Fe}$ rich chlorite. The fluid responsible for this interaction was $\mathrm{Mg}$-rich, with a ${ }^{87} \mathrm{Sr} /{ }^{86} \mathrm{Sr} \approx 0.7038$ to 0.7042 ; most probably a mixture of upwelling, high-temperature $\left(>300^{\circ} \mathrm{C}\right)$, black smoker- 
type fluid with a minor $(<10 \%)$ proportion of seawater. Plagioclase within these alteration halos is partially recrystallized to secondary minerals. Alteration progressed by the dissolution of basaltic phases and precipitation of chlorite.

Continued high-temperature $\left(>300^{\circ} \mathrm{C}\right)$ interaction between the wallrock and initially $\mathrm{Mg}$-bearing hydrothermal fluids resulted in the development of chloritized basalts. These green rocks comprise chlorite + quartz + pyrite, and were altered by fluids of similar composition to the chloritic alteration halos, though recrystallization is complete and sulfide mineralization more extensive.

Other hydrothermal assemblages overprint the relatively early chloritized basaltic breccias. These rocks comprise assemblages of paragonite + quartz + pyrite and precipitated at high temperatures $\left(300^{\circ}-363^{\circ} \mathrm{C}\right)$ from magnesium-depleted, hydrothermal fluids with ${ }^{87} \mathrm{Sr} /{ }^{86} \mathrm{Sr} \approx 0.7038$. The absence of hydrothermal rocks with ${ }^{87} \mathrm{Sr} /{ }^{86} \mathrm{Sr}$ less than 0.7038 suggests end-member black smoker fluids responsible for the mineralization in the TAG mound had strontium-isotopic compositions similar to present-day fluids $(\approx 0.7038$, Edmond et al., 1995). $\delta^{18} \mathrm{O}$ of quartz and whole-rock ${ }^{87} \mathrm{Sr} /{ }^{86} \mathrm{Sr}$ indicate that conductive cooling was the major process affecting fluids during silicification and sulfide mineralization of the stockwork, with only minor («10\%) mixing with seawater after the initial phase of chloritic alteration. Elevated ${ }^{87} \mathrm{Sr} /{ }^{86} \mathrm{Sr}$ ratios, recorded by some samples from the TAG stockwork, are best explained by minor contamination by latestage anhydrite.

Hydrothermal assemblages from the stockwork at TAG-4 yield a similar restricted range of ${ }^{87} \mathrm{Sr} /{ }^{86} \mathrm{Sr}(0.7039-0.7041)$ to stockwork samples from areas of high heat flow, active venting, and abundant anhydrite precipitation (TAG-1, TAG-2, and TAG-5). The absence of anhydrite in the TAG- 4 drill cores implies that the subsurface of the mound and stockwork in this area is relatively $\operatorname{cool}\left(<150^{\circ} \mathrm{C}\right)$. The consistency of the ${ }^{87} \mathrm{Sr} /{ }^{86} \mathrm{Sr}$ ratios of hydrothermal assemblages throughout the mound and stockwork requires that the ${ }^{87} \mathrm{Sr} /{ }^{86} \mathrm{Sr}$ ratio of end-member hydrothermal fluids has remained relatively constant for a time period longer than that required to change the interior thermal structure and plumbing network of the mound and underlying stockwork.

The precipitation of anhydrite in breccias and as late-stage veins throughout the mound and stockwork records extensive mixing of hydrothermal fluids with seawater (see Teagle et al., Chap. 11; Chiba et al., Chap. 6; Mills et al., Chap. 10; all in this volume). In contrast however, the silicification and sulfide mineralization that dominate the stockwork and interior of the mound occurred by interaction of end-member black smoker fluids with basalt and early hydrothermally altered rocks, with limited conductive cooling. The dilution of hydrothermal fluids by mixing with seawater played only a minor role in the development of the quartz-sulfide stockwork.

\section{ACKNOWLEDGMENTS}

The authors gratefully acknowledge Jim R. O'Neil for the use of his laboratory (oxygen isotopes), John N. Christensen and Mark Brandriss for invaluable technical assistance, and Eleanor T. Dixon for sample preparation. Reviews by Mike Bickle, Richard Carlson and Laura Stokking helped clarify some of the interpretations presented here. This work was supported by grants from JOI-USSAC to DAHT, JCA, and SEH.

\section{REFERENCES}

Alt, J.C., Honnorez, J., Laverne, C., and Emmermann, R., 1986. Hydrothermal alteration of a $1 \mathrm{~km}$ section through the upper oceanic crust, Deep Sea Drilling Project Hole 504B: mineralogy, chemistry, and evolution of seawater-basalt interactions. J. Geophys. Res., 91:10309-10335.
Becker, K., and Von Herzen, R.P., 1996. Pre-drilling observations of conductive heat flow at the TAG active mound using Alvin. In Humphris, S.E., Herzig, P.M., Miller, D.J., et al., Proc. ODP, Init. Repts., 158: College Station, TX (Ocean Drilling Program), 23-29.

Bickle, M.J., and Teagle, D.A.H., 1992. Strontium alteration in the Troodos ophiolite: implications for fluid fluxes and geochemical transport in midocean ridge hydrothermal systems. Earth Planet. Sci. Lett., 113:219-237.

Bischoff, J.L., and Seyfried, W.E., 1978. Hydrothermal chemistry of seawater from $25^{\circ} \mathrm{C}$ to $350^{\circ} \mathrm{C}$. Am. J. Sci., $278: 838-860$.

Bowers, T.S., Campbell, A.C., Measures, C.I., Spivack, A.J., Khadem, M., and Edmond, J.M., 1988. Chemical controls on the composition of vent fluids at $13^{\circ}-11^{\circ} \mathrm{N}$ and $21^{\circ} \mathrm{N}$, East Pacific Rise. J. Geophys. Res., 93:4522-4536.

Campbell, A.C., Palmer, M.R., Klinkhammer, G.P., Bowers, T.S., Edmond, J.M., Lawrence, J.R., Casey, J.F., Thompson, G., Humphris, S., Rona, P.A., and Karson, J.A., 1988. Chemistry of hot springs on the Mid-Atlantic Ridge. Nature, 335:514-519.

Constantinou, G., and Govett, G.J.S., 1973. Geology, geochemistry, and genesis of Cyprus sulfide deposits. Econ. Geol., 68:843-858.

Craig, H., 1961. Standard for reporting concentrations of deuterium and oxygen-18 in natural waters. Science, 133:1833-1834.

Edmond, J.M., Campbell, A.C., Palmer, M.R., German, C.R., Klinkhammer, G.P., Edmonds, H.N., Elderfield, H., Thompson, G., and Rona, P., 1995. Time-series studies of vent fluids from the TAG and MARK sites (1986, 1990): Mid-Atlantic Ridge: a new solution chemistry model and a mechanism for $\mathrm{Cu} / \mathrm{Zn}$ zonation in massive sulfide ore bodies. In Parson, L.M., Walker, C.L., and Dixon, D.R. (Eds.), Hydrothermal Vents and Processes. Geol. Soc. Spec. Publ. London, 87:77-86.

Edmond J.M., Measures, C., Magnum, B., Grant, B., Sclater, F.R., Collier, R., Hudson, A., Gordon, L.I., and Corliss, J.B., 1979. On the formation of metal-rich deposits at ridge crests. Earth. Planet. Sci. Lett., 46:19-30.

Elderfield, H., Mills, R. A., and Rudnicki, M. D., 1993. Geochemical and thermal fluxes, high-temperature venting and diffuse flow from midocean ridge systems: the TAG hydrothermal field, Mid-Atlantic Ridge $26^{\circ}$ N. In Prichard, H.M., Alabaster, T., Harris, N.B.W., and Neary, C.R. (Eds.), Magmatic Processes and Plate Tectonics Geol. Soc. Spec. Publ. London, 76:295-307.

Evans, R.L., 1996. A seafloor gravity profile across the TAG hydrothermal mound. Geophys. Res. Lett., 23:3447-3450.

German, C.R., Mills, R.A., Blusztaln, J., Fleer, A.P., Bacon, M.P., Higgs, N.C., Elderfield, H., and Thompson, J., 1993. A geochemical study of metalliferous sediment from the TAG hydrothermal field, $26^{\circ} 08^{\prime} \mathrm{N}$, MAR. J. Geophys. Res., 98: 9683-9692.

Gregory, R.T., and Taylor, H.P., Jr., 1981. An oxygen isotope profile in a section of Cretaceous oceanic crust, Samail ophiolite, Oman: evidence for $\delta^{18} \mathrm{O}$-buffering of the oceans by deep ( $\left.>5 \mathrm{~km}\right)$ seawater-hydrothermal circulation at mid-ocean ridges. J. Geophys. Res., 86:2737-2755.

Hannington, M.D., Jonasson, I.R., Herzig, P.M., and Petersen, S., 1995. Physical, chemical processes of seafloor mineralization at mid-ocean ridges. In Humphris, S.E., et al. (Eds.), Seafloor Hydrothermal Systems: Physical, Chemical, Biological and Geological Interactions. Am. Geophys. Union Monogr., 91:115-157.

Haymon, R.M., and Kastner, M., 1981. Hot spring deposits on the East Pacific Rise at $21^{\circ} \mathrm{N}$ : preliminary description of mineralogy and genesis. Earth Planet. Sci. Lett., 53:363-381.

Hodell, D.A., Mueller, P.A., and Garrido, J.R., 1991. Variations in the strontium isotopic composition of seawater during the Neogene. Geology, 19:24-27.

Humphris, S.E., Herzig, P.M., Miller, D.J., Alt, J.C., Becker, K., Brown, D., Brügmann, G., Chiba, H., Fouquet, Y., Gemmell, J.B., Guerin, G., Hannington, M.D., Holm, N.G., Honnorez, J.J., Itturino, G.J., Knott, R., Ludwig, R., Nakamura, K., Petersen, S., Reysenbach, A.-L., Rona, P.A., Smith, S., Sturz, A.A., Tivey, M.K., and Zhao, X., 1995. The internal structure of an active sea-floor massive sulphide deposit. Nature, 377:713-716.

Humphris, S.E., Herzig, P.M., Miller, D.J., et al., 1996. Proc. ODP, Init. Repts., 158: College Station, TX (Ocean Drilling Program).

James, R., and Elderfield, H., 1996. Chemistry of ore-forming fluids and mineral formation rates in an active hydrothermal sulfide deposit on the Mid-Atlantic Ridge. Geology, 24:1147-1150.

James, R.H., Elderfield, H., and Palmer, M.R., 1995. The chemistry of hydrothermal fluids from the Broken Spur site, $29^{\circ} \mathrm{N}$ Mid-Atlantic Ridge. Geochim. Cosmochim. Acta, 59:651-659. 
Janecky, D.R., and Seyfried, W.E., 1984. Formation of massive sulfide deposits on oceanic ridge crests: incremental reaction models for mixing between hydrothermal solutions and seawater. Geochim. Cosmochim. Acta, 48:2723-2738.

Karson, J.A., and Rona, P.A., 1990. Block tilting, transfer faults, and structural control of magmatic and hydrothermal processes in the TAG area, Mid-Atlantic Ridge $26^{\circ}$ N. Geol. Soc. Am. Bull., 102:1635-1645.

Kleinrock, M.C., Humphris, S.E., and the Deep-TAG Team, 1996. Detailed structure and morphology of the TAG active hydrothermal mound and its geotectonic environment. In Humphris, S.E., Herzig, P.M., Miller, D.J., et al., Proc. ODP, Init. Repts., 158: College Station, TX (Ocean Drilling Program), 15-21.

Lalou, C., Reyss, J.L., Brichet, E., Arnold, M., Thompson, G., Fouquet, Y., and Rona, P.A., 1993. New age data for Mid-Atlantic Ridge hydrothermal sites: TAG and Snakepit geochronology revisited. J. Geophys. Res., 98:9705-9713.

Lalou, C., Reyss, J.-L., Brichet, E., Rona, P.A., and Thompson, G., 1995. Hydrothermal activity on a $10^{5}$-year scale at a slow-spreading ridge, TAG hydrothermal field, Mid-Atlantic Ridge $26^{\circ}$ N. J. Geophys. Res., 100:17855-17862.

Lister, C.R.B., 1972. On the thermal balance of a mid-ocean ridge. Geophys. J. R. Astron. Soc., 26:515-535.

Masuda, H., Chiba, H., Gamo, T., Fujioka K., and Nakamura, M., 1995. Distribution and chemical characteristics of hydrothermal alteration minerals recovered from the TAG active mound, MAR $26^{\circ} \mathrm{N}$. JAMSTEC J. Deep Sea Res., 11:111-124.

McGregor, B.A., Harrison, C.G.A., Lavelle, J.W., and Rona, P.A., 1977. Magnetic anomaly patterns on Mid-Atlantic Ridge crest at $26^{\circ}$ N. J. Geophys. Res., 82:231-238.

Mills, R.A., and Elderfield, H., 1995. Rare earth element geochemistry of hydrothermal deposits from the active TAG mound, $26^{\circ} \mathrm{N}$ Mid-Atlantic Ridge. Geochim. Cosmochim. Acta, 59:3511-3524.

Mills, R.A., Elderfield, H., and Thompson, J., 1993. A dual origin for the hydrothermal component in a metalliferous sediment core from the MidAtlantic Ridge. J. Geophys. Res., 98:9671-9681.

Muehlenbachs, K., and Clayton, R.N., 1972. Oxygen isotope studies of fresh and weathered submarine basalts. Can. J. Earth Sci., 9:172-184.

Palmer, M.R., and Edmond, J.M., 1989. The strontium isotope budget of the modern ocean. Earth Planet. Sci. Lett., 92:11-26.

Richardson, C.J., Cann, J.R., Richards, H.G., and Cowan, J.G., 1987. Metaldepleted root zones of the Troodos ore-forming hydrothermal systems, Cyprus. Earth Planet. Sci. Lett., 84:243-253.

Ridley, W.I., Perfit, M.R., Jonasson, I.R., and Smith, M.F., 1994. Hydrothermal alteration in oceanic ridge volcanics: a detailed study at the Galapagos fossil hydrothermal field. Geochim. Cosmochim. Acta, 58:24772494.

Rona, P.A., Hannington, M.D., Raman, C.V., Thompson, G., Tivey, M.K., Humphris, S.E., Lalou, C., and Petersen, S., 1993. Active and relict seafloor hydrothermal mineralization at the TAG hydrothermal field, MidAtlantic Ridge. Econ. Geol., 88:1987-2013.

Rona, P.A., Klinkhammer, G., Nelson, T.A., Trefry, J.H., and Elderfield, H., 1986. Black smokers, massive sulfides and vent biota on the Mid-Atlantic Ridge. Nature, 321:33-37.

Rona, P.A., McGregor, B.A., Betzer, P.R., Bolger, G.W., and Krause, D.C., 1975. Anomalous water temperatures over Mid-Atlantic Ridge Crest at $26^{\circ}$ N. Deep-Sea Res. Part A, 22:611-618.

Savin, S.M., and Lee, M., 1988. Isotopic studies of phyllosilicates. In Bailey, S.W. (Ed.), Hydrous Phyllosilicates (Exclusive of Micas). Min. Soc. Am., Rev. Mineral., 19:189-223.

Schiffman, P., Smith, B.M., Varga, R.J., and Moores, E.M., 1987. Geometry, conditions, and timing of off-axis hydrothermal metamorphism and oredeposition in the Solea Graben. Nature, 325:423-425.
Shanks, W.C., III., Böhlke, J.K., Seal, R.R., II, 1995. Stable isotopes in midocean ridge hydrothermal systems: interactions between fluids, minerals, and organisms. In Humphris, S.E., Zierenberg, R.A., Mullineaux, L.S., Thompson, R.E. (Eds.), Seafloor Hydrothermal Systems: Physical, Chemical, Biological, and Geological Interactions. Geophys. Monogr., 91:194-221.

Sharp, Z.D., and Kirschner, D.L., 1994. Quartz-calcite oxygen isotope geothermometry: a calibration based on natural isotopic variations. Geochim. Cosmochim. Acta, 58:4491-4502.

Stein, C.A., and Stein, S., 1994. Constraints on hydrothermal heat flux through the oceanic lithosphere from global heat flow. J. Geophys. Res., 99:3081-3095.

Teagle, D.A.H., 1993a. The formation of Epidosite in the Phterykhoudhi Potamos gorge, Troodos ophiolite, Cyprus. Eos, 74:666.

1993b. A study of hydrothermal alteration of the Troodos Ophiolite, Cyprus: petrological, geochemical and strontium isotopic constraints [Unpubl. Ph.D. thesis]. Univ. of Cambridge.

Teagle, D.A.H., Alt, J.C., Bach, W., Halliday, A.N., and Erzinger, J., 1996. Alteration of upper ocean crust in a ridge-flank hydrothermal upflow zone: mineral, chemical, and isotopic constraints from Hole 896A. In Alt, J.C., Kinoshita, H., Stokking, L.B., and Michael, P.J. (Eds.), Proc. ODP, Sci. Results, 148: College Station, TX (Ocean Drilling Program), 119150.

Thompson, G., Humphris, S.E., Schroeder, B., Sulanowska, M., and Rona, P.A., 1988. Active vents and massive sulfides at $26^{\circ} \mathrm{N}(\mathrm{TAG})$ and $23^{\circ} \mathrm{N}$ (Snakepit) on the Mid-Atlantic Ridge. Can. Mineral., 26:697-711.

Thompson, G., Mottl, M.J., and Rona, P.A., 1985. Morphology, mineralogy and chemistry of the hydrothermal deposits from TAG area, $26^{\circ} \mathrm{N}$, MidAtlantic Ridge. Chem. Geol., 49:243-257.

Tivey, M.A., Rona, P.A., and Schouten, H., 1993. Reduced crustal magnetization beneath the active sulfide mound, TAG hydrothermal field, MidAtlantic Ridge $26^{\circ}$ N. Earth Planet. Sci. Lett., 115:101-115.

Tivey, M.K., 1995. Modeling chimney growth and associated fluid flow at seafloor hydrothermal vent sites. In Humphris, S.E., Zierenberg, R.A., Mullineaux, L.S., and Thomson, R.E. (Eds.), Seafloor Hydrothermal Systems: Physical, Chemical, Biological and Geological Interactions. Am. Geophys. Union, Geophys. Monogr., 91:158-177.

Tivey, M.K., Humphris, S.E., Thompson, G., Hannington, M.D., and Rona, P.A., 1995. Deducing patterns of fluid flow and mixing within the TAG active hydrothermal mound using mineralogical and geochemical data. $J$. Geophys. Res., 100:12527-12555.

Von Damm, K.L., Edmond, J.M., Grant, B., Measures, C.I., Walden, B., and Weiss, R.F., 1985. Chemistry of submarine hydrothermal solutions at $21^{\circ}$ N, East Pacific Rise. Geochim. Cosmochim. Acta, 49:2197-2220.

Zierenberg, R.A., Shanks, W.C., III, Seyfried, W.E., Jr., Koski, R.A., and Strickler, M.D., 1988. Mineralization, alteration, and hydrothermal metamorphism of the ophiolite-hosted Turner-Albright sulfide deposit, southwestern Oregon. J. Geophys. Res., 93:4657-4674.

Zonenshain, L.P., Kuzmin, M.I., Lisitsin, A.P., Bogdanov, Y.A., and Baranov, B.V., 1989. Tectonics of the Mid-Atlantic rift valley between the TAG and MARK areas $\left(26-24^{\circ} \mathrm{N}\right)$ : evidence for vertical tectonism. Tectonophysics, 159:1-23.

Date of initial receipt: 3 June 1996

Date of acceptance: 10 June 1997

Ms 158SR-231 